\title{
Chemical reactivity and supramolecular susceptibility of hardwood celluloses towards succinic anhydride
}

\author{
Rodrigue SAFOU-TCHIAMA ${ }^{1,2 *}$, Timoléon ANDZI BARHÉ ${ }^{1}$, \\ Patrice SOULOUNGANGA ${ }^{3}$, Sébastien NGWA OBAME ${ }^{2}$, \\ Saint-Bickolard MABICKA IWANGOU ${ }^{2}$, Arsène BIKORO BI ATHOMO ${ }^{2}$, \\ Péguy Starlin ENGOZOGHO ANRIS ${ }^{2}$, Bernard De JESO ${ }^{4}$ and \\ Aristide Gervais AKAGAH ${ }^{1}$
}

\footnotetext{
${ }^{1}$ Laboratoire des Substances Naturelles et de Synthèse Organométalliques (LASNSOM). Unité de Recherche en Chimie. Université des Sciences et Techniques de Masuku. BP. 941 Franceville, Gabon.

${ }^{2}$ Laboratoire de Recherche et de Valorisation du Matériau Bois (LaReVa Bois). Bât du Master Recherche en Sciences du Bois. Ecole Nationale des Eaux et Forêts. BP 3960, Libreville, Gabon.

${ }^{3}$ Laboratoire Pluridisciplinaire des Sciences. Ecole Normale Supérieure. BP. 17009, Libreville, Gabon.

${ }^{4}$ Laboratoire de Chimie des Polymères Organiques (LCPO) ; UMR 5629. 16 Avenue Pey Berland, 33607

Pessac France.

*Corresponding author; E-mail: r_safoutchiama@yahoo.fr; Tel:+241 02457765
}

\begin{abstract}
In order to understand the chemical reactivity and the relative susceptibility of $\mathrm{I}_{\alpha}$ and $\mathrm{I}_{\beta}$ cellulose allomorphs of some tropical hardwoods with coupling agents bearing succinic moiety, their cellulose fibers were isolated and esterified by succinic anhydride molecule heated at $120{ }^{\circ} \mathrm{C}$ for $4 \mathrm{~h}$ in dimethylformamide(DMF)/pyridine(Py) used as swelling solvent. The morphological structure of Testulea gabonensis (T. gabonensis), Julbernardia pellegriniana (J. pellegriniana), Aucoumea klaineana (A. klaineana) and Tieghemella africana (T. africana) fibers were characterized by the MORFI ${ }^{\circ}$ apparatus. The fibers were the longest for T. africana $(769 \mu \mathrm{m})$, J. pellegriniana $(717 \mu \mathrm{m})$ and $T$. gabonensis $(700 \mu \mathrm{m})$ while those from A. klaineana were the shortest $(624 \mu \mathrm{m})$. No difference was found between T. gabonensis, A. klaineana and T. africana fibers width which varied from 24.0 to $24.2 \mu \mathrm{m}$ while $J$. pellegriniana cellulose exhibited the smallest width $(18.6 \mu \mathrm{m})$. The cellulose fibers of T. gabonensis, T. africana and J. pellegriniana displayed the better reactivity as revealed by their respective weigh per cent gains: $16.57 \pm 1.11 \%, 14.16 \pm 0.67 \%$ and $12.96 \pm 0.77 \%$ compared with A. klaineana $(11.85 \pm 0.62 \%)$. The latter exhibited the lowest decrease of crystallinity among those cellulose esters. Nevertheless, solid state ${ }^{13} \mathrm{C}$ NMR showed a strong reactivity of amorphous cellulose and chains exposed on crystal surfaces than interior crystallite chains. Any evidence of $\mathrm{I}_{\alpha}$ and $\mathrm{I}_{\beta}$ allomorphs esterification was found in those cellulose fibers with the exception of $T$. africana which displayed a decrease of $\mathrm{I}_{\alpha}$ and $\mathrm{I}_{\beta}$ allomorphs without a preferential reactivity of $\mathrm{I}_{\alpha}$ cellulose. The trend of heterogeneous phase esterification of cellulose fibers with succinic anhydride in DMF/Py at $120{ }^{\circ} \mathrm{C}$ for 4 hours to be merely controlled by amorphous phase and chains exposed on crystal surface was discussed.
\end{abstract}

(C) 2017 International Formulae Group. All rights reserved.

Keywords: Cellulose allomorphs, Esterification, Solid state NMR, X-ray diffraction. 


\section{INTRODUCTION}

Cellulose is a natural and complex polymer biosynthesized by plant, algae and tunicate in animals. That biopolymer was found by Payen (1838) and described as resistant and fibrous. The hierarchical structure of cellulose, formed by hydrogen bond network between hydroxyl groups has been subject of intense research and marked by regular controversies over results and consistent supply of new insight (Atalla, 1987). The utilization of lignocellulose wastes for cellulose production increases interest worldwide and in sub-saharan countries in particular. That is how the degradability of cellulose in maize cob used for animals feed in Ghana was investigated by Adamafio et al. (2009), and the capability of pumpkin cellulose to remove heavy metals was recently studied in Nigeria (Eze et al., 2013). The trend of Abelmuscus esculentus powder to have good swelling and hydration aptitude displayed its strong potential as pharmaceutical raw material in tablet formulation (Bakre and Jaiyeoba, 2009). Other scientists investigated the impact of non-structural carbohydrates on wood teak from Malaysia. Their findings have pointed out the key role of sugars like starch, sucrose and glucose stored as reserve materials in the sapwood or used for metabolic activities during heartwood formation process (Niamke et al., 2010). Recently, enzymatic hydrolysis of the cellulose-hemicellulose matrix of $A$. klaineana wood wastes from Gabon pointed out the strong capability of that hardwood species to produce neutral sugars suitable for cellulose ethanol or biomolecules (SafouTchiama et al., 2016). Nevertheless, progress in X-ray diffraction (XRD) have shown in first approximation that the native cellulose (cellulose I) has a monoclinic unit cell which contains two cellulose chains in parallel orientation with a twofold screw axis (Gardner and Blackwell, 1974). The cellulose structure investigated by Atalla and Van der Hart (1984a) in high-resolution solid state ${ }^{13} \mathrm{C}$ NMR spectroscopy $\left({ }^{13} \mathrm{C} \quad \mathrm{CP} / \mathrm{MAS} \quad \mathrm{NMR}\right)$ pointed out that native cellulose is present in two different cellulose forms, the $\mathrm{I}_{\alpha}$ and $\mathrm{I}_{\beta}$ allomorphs. The $\mathrm{I}_{\alpha} / \mathrm{I}_{\beta}$ ratio depends on the origin of cellulose (Maunu et al., 2000; Kono et al., 2002).

The biological and numerous applications of cellulose are based on the morphology of the fibers. That morphology is defined by elementary fibrils, microfibrils and microfibrillar bands (Habibi et al., 2012). Microfibrillar bands are composed with crystalline and non-crystalline regions of varying dimension. That morphological structure of cellulose was extensively studied by XRD for many years; it controls not only the access of solvents within the fibers, but also the chemical reactivity of that polymer (Papadopoulos et al., 2003; Aimin et al., 2005). However, the supramolecular structure of cellulose showed susceptibility to chemical treatments such as alkalization which modified the crystallinity of cellulose treated with sodium hydroxide (Mwaikambo and Ansell, 2002). Moreover, other chemical treatments including periodate solution decreased also the cellulose order as revealed by XRD and ${ }^{13} \mathrm{C}$ CP/MAS NMR (Zimnitsky et al., 2004). Nevertheless, the decrease of cellulose crystallinity was function of fibers' origin (Mwaikambo and Ansell, 2002).

Furthermore, the decrease of the lattice order in the fibers suggests that cellulose $\mathrm{I}_{\alpha}$ and cellulose $\mathrm{I}_{\beta}$ chains, respectively located on crystals surface and interior crystals should have been subject to chemical reaction. However, solid state NMR of cellulose from various sources pointed out preferential hydrolysis of $\mathrm{I}_{\alpha}$ allomorph for yellow poplar (Davis et al., 2004), Cladophora (Hayashi et al., 1998, 2005) and southern pine (Pu et al., 2006) treated with various enzymatic systems. The preferential reactivity of cellulose $\mathrm{I}_{\alpha}$ over $\mathrm{I}_{\beta}$ was also observed for acetylated Valonia cellulose (Sassi et al., 2000; Yamamoto et al., 2006). Since cellulose $I_{\alpha}$ is generally considered thermodynamically less stable and more reactive than cellulose $\mathrm{I}_{\beta}$; recent study have shown that cellulose TEMPO-oxidized didn't exhibit preferential reactivity of $\mathrm{I}_{\alpha}$ 
compared with $\mathrm{I}_{\beta}$ allomorph (Carlsson et al., 2015).

Esterification of cellulose in heterogeneous medium with cyclic anhydrides have also been widely used in various applications like absorbents for soil in agriculture, natural absorbents for the removal of heavy metals in wastewater treatment, medicine for drug delivery systems, and thermoplastic materials (Hadano et al., 2003; Yoshimura et al., 2006; Gurgel et al., 2008). However, the reaction results in pendant carboxylic moiety attached to cellulose via covalent ester bond, providing like this a site upon which further chemical reactions are possible. That render succinic anhydride proper candidate for coupling agents in wood composite materials.

The capability of that cyclic anhydride to increase the interfacial bonding of some tropical woods was investigated (SafouTchiama et al., 2007). It was noteworthy that esterification of wood sawdust with succinic anhydride decreased the crystallinity index of the samples and displayed an inter-species variability. Though that succinic anhydride used in ionic liquid medium decreased the molecular order of sugarcane bagasse or rice straw cellulose (Liu et al., 2007, 2011, 2013); the behavior of $T$. gabonensis, $J$. pellegriniana, A. klaineana and T. africana cellulose fibers regarding the supramolecular susceptibility and the chemical reactivity remains unsolved. Despite that the reactivity of those hardwood cellulose-hemicellulose complexes and their lignin structure and reactivity have been investigated (SafouTchiama et al., 2007, 2017); the stability of their cellulose crystalline phases as well as $\mathrm{I}_{\alpha}$ and $\mathrm{I}_{\beta}$ allomorphs reactivity towards succinic anhydride remains unknown.

The aim of this study was to investigate the supramolecular structure and the accessibility of succinic anhydride to the hydroxyl groups of the selected hardwood celluloses, in order to understand the decrease of the crystallinity observed when their sawdust were esterified by succinic anhydride molecule.

\section{MATERIALS AND METHODS Chemicals}

Succinic

anhydride

(SA), dimethylformamide (DMF), pyridine (Py), toluene, acetone, hydrogen peroxide $\left(\mathrm{H}_{2} \mathrm{O}_{2}\right)$, acetic acid $\left(\mathrm{CH}_{3} \mathrm{COOH}\right)$ and methanol $\left(\mathrm{CH}_{3} \mathrm{OH}\right)$ were purchased from Aldrich. Solvents were used without further purification. DMF and Py were dried prior to use with a $4 \mathrm{~A}^{\circ}$ molecular sieves.

\section{Wood samples collection}

The wood samples were obtained from the heartwood of $T$. gabonensis, $J$. pellegriniana, A. klaineana and T. africana $\operatorname{logs}$ sawing wastes of the SED (Société Equatoriale de Déroulage) company. The logs were collected at Nzamaligue forest (Estuary Province, near to Libreville, in Gabon).

\section{Extraction of the cellulose fibers \\ Extraction of the holocellulose fibers}

The holocellulose of each wood species was obtained from an adaptation of previously published procedures (Pichavant and Mercier, 1998; Sun et al., 1999) as follows: $9.7 \mathrm{~g}$ of dried wood chips, previously extracted by a toluene: acetone: methanol $(4: 1: 1, \mathrm{v} / \mathrm{v} / \mathrm{v})$ mixture for $12 \mathrm{~h}$ and leached by hot distilled water for $10 \mathrm{~h}$. The extractives free wood chips were air dried for three days and drier under vacuum at $105{ }^{\circ} \mathrm{C}$ for $16 \mathrm{~h}$. The dried wood samples were stirring impregnated in a round bottomed flask containing a sodium acetate solution composed with $\mathrm{H}_{2} \mathrm{O}(240 \quad \mathrm{ml}) / \mathrm{NaOH}(6$ $\mathrm{g}) / \mathrm{CH}_{3} \mathrm{COOH}(18 \mathrm{ml})$, and maintained at 75 ${ }^{\circ} \mathrm{C}$ for 6 hours. Then, $16.67 \mathrm{ml}$ of sodium chlorite solution $(10 \%, \mathrm{w} / \mathrm{v})$ was added each hour. The cellulose-hemicelluloses complex were filtered, washed with distilled water until $\mathrm{pH}=7$ and dried at $105{ }^{\circ} \mathrm{C}$ for 15 hours. The residual lignin was removed from the bleached fibers with a solution of $\mathrm{CH}_{3} \mathrm{COOH} / \mathrm{H}_{2} \mathrm{O}_{2}(1: 3, \mathrm{v} / \mathrm{v})$ heated at $75^{\circ} \mathrm{C}$ for $3 \mathrm{~h}$.

\section{Extraction of the cellulose fibers}

The cellulose fibers were obtained from the bleached holocellulose with a mixture of $\mathrm{NaOH}(8 \%) / \mathrm{Na}_{2} \mathrm{~B}_{4} \mathrm{O}_{7} \cdot 10 \mathrm{H}_{2} \mathrm{O}(1 \%)$ 
(w/v) according to Sun et al. (1999). To remove the residual lignin and the neutral hemicellulose sugars incrusted in the final cellulose pulp, the fibers obtained were treated with a mixture of $\mathrm{CH}_{3} \mathrm{COOH} / \mathrm{H}_{2} \mathrm{O}_{2}(1: 3, \mathrm{v} / \mathrm{v})$ at $75{ }^{\circ} \mathrm{C}$ for $3 \mathrm{~h}$. The resulting material was air dried for three days. Then, the dryness of the pulp was controlled with an analytical and accurate balance of $0.1 \mathrm{mg}$. The purity of the cellulose fibers was determined by calculating the residual Klason lignin content according to TAPPI standard method (Tappi, 1988). All the samples exhibited a very low residual lignin content $(<0.5 \%)$. The percentage of cellulose $(\mathrm{w} / \mathrm{w})$ was calculated as follows:

$$
\text { Cellulose }(\%)=\frac{M_{d, \text { cell }}}{M_{e, d}} \times 100
$$

$M_{e, d}$ was the extracted free oven-dried wood sawdust weight, while $M_{d, \text { cell }}$ was the free oven-dried cellulose fibers weight.

The total residual xylose, galactose, arabinose and mannose neutral sugars covering or crusting the cellulose fibers was determined by high performance liquid chromatography (HPLC) as described elsewhere (Safou-Tchiama et al., 2007).

\section{Morphological analysis of cellulose fibers}

The calculation of cellulose fibers length and width was carried out with a MORFI ${ }^{\circledR}$ LABO (LB-01) as follows: $0.4 \mathrm{~g}$ $(\approx 4000$ fibers $)$ of air dried cellulose fibers were soaked in $20 \mathrm{ml}$ of hot distilled water for 10 minutes, separated for 30 second with a blender in a jigger containing $250 \mathrm{ml}$ of distilled water. Then, the mixture was analysed with the MORFI ${ }^{\circledR}$ apparatus.

\section{Observation of the fibers and vessel elements by optic microscopy}

$1.0 \mathrm{~g}$ of cellulose was soaked in $20 \mathrm{ml}$ of distilled water and maintained under magnetic agitation for 3 minutes. Three drops of the fibers solutions were taken off with a pipette and deposited on a flake, and three drops of Sellenger colorant was cautiously poured on the fiber solutions with a pipette. A cover-glass was carefully set down above the colored fibers to avoid bubbles of air between the blade and the gill. Then, the fibers and vessel structure elements were observed with a binocular optic microscope "Motic 2.0" to a magnification of forty $\mathrm{x}$. The observation was facilitated by a Ken-A-Vision camera connected to a computer. The software Vision 4 allowed taking fibers and vessel elements pictures.

\section{Grafting of succinic anhydride onto cellulose fibers}

Prior to any chemical modification, the cellulose fibers were dried at $105^{\circ} \mathrm{C}$ for $16 \mathrm{~h}$, kept for $30 \mathrm{~min}$ in a desiccator containing $\mathrm{P}_{2} \mathrm{O}_{5}$ and the weight of dried cellulose samples $\left(M_{0}\right)$ was measured. The required weight of succinic anhydride molecules $\left(m_{\mathrm{SA}}\right)$ was calculated as follows: $m_{\mathrm{SA}}=0.997 \times M_{0}$ and the corresponding volumes of DMF and Py were such as $\mathrm{V}_{\mathrm{DMF}}=2 \mathrm{~V}_{\mathrm{Py}}=21.2 \mathrm{x} M_{0}$. The dried cellulose samples were stirring impregnated for $10 \mathrm{~min}$ with pyridine heated at $120^{\circ} \mathrm{C}$ in a round bottomed wide-mounted flask equipped with a condenser and a calcium chloride drying tube, and succinic anhydride diluted in DMF was add in the mixture and stirred under reflux at $120{ }^{\circ} \mathrm{C}$ for $4 \mathrm{~h}$. The succinylated cellulose fibers were soxhlet extracted with acetone for $4 \mathrm{~h}$ to remove the excess of succinic anhydride and oven dried for $16 \mathrm{~h}$ at $105{ }^{\circ} \mathrm{C}$. The resulting cellulose esters were kept under vacuum in a desiccator containing $\mathrm{P}_{2} \mathrm{O}_{5}$ for $15 \mathrm{~min}$, and the dried weight of succinylated cellulose $\left(M_{\mathrm{SA}}\right)$ was determined. The weight percent gain (WPG) was calculated as follows:

$$
W P G(\%)=\frac{M_{S A}-M_{0}}{M_{0}} \times 100
$$

\section{${ }^{13} \mathrm{C}$ CP/MAS NMR characterization}

The solid state ${ }^{13} \mathrm{C}$ CP/MAS (Cross Polarization-Magic Angle Spinning) NMR spectra of cellulose fibers were performed at 100.612 MHz on a Bruker DPX-400 NMR spectrometer equipped with a solid multinuclear probe. To avoid any hydrolysis of ester bonds in the cellulose esters, the samples were not wet. The dry cellulose 
powder put into a zirconium oxide rotor (4 $\mathrm{mm}$ internal diameter), using the cross polarization technique and magic angle spinning (CP/MAS) at 4 and $8 \mathrm{kHz}$. All the spectra were run for $15 \mathrm{~h}$ (25000 scans). The Bruker pulse program was CP3LE.drx. The acquisition and the contact time were of 0.068 $\mathrm{s}$ and $1500 \mu \mathrm{s}$ respectively. Resolution enhanced spectra was handled in the following manner: for each spectrum, the free induction decay (FID) was not subject to DC correction. The Gaussian Lorenz multiplication with the Gaussian broadening was $\mathrm{Lb}=-120 \mathrm{~Hz}$ and $\mathrm{Gb}=0.1$, respectively. The spectra were smoothened, and the phase was automatically corrected.

The chemical shifts $(\delta / \mathrm{ppm})$ of all the samples were calibrated relative to trimethylsilane $\left(\left(\mathrm{CH}_{3}\right)_{4} \mathrm{Si}\right)$. Spectra were deconvoluted after baseline correction of the area of interest with a Bruker software deconvolution program. Then, the crystallinity index $(X)$ of interior crystallites and amorphous chains was calculated in the range 91-80 ppm (C-4) from signals centered at 89.4-89.2 and at 84.5-84.2 ppm as described by Newman and Hemmington (1990).

The $X$ values were calculated from the unenhanced spectra as follows:

$$
X(\%)=\frac{I_{c r}}{I_{c r}+I_{a m}} \times 100
$$

$I_{c r}$ was the integrated area of the peak centered at 89.4-89.2 ppm assigned to interior crystalline cellulose and $I_{a m}$ was the integrated area of peaks centered at 84.5-84.2 ppm corresponding to amorphous cellulose and chains on crystal surface. The cellulose crystallite dimension $(L)$ was estimated from the crystallinity index as proposed by Newman (1999a):

$$
L(n m)=\frac{2 h}{1-\sqrt{X}}
$$

$h=0.57 \mathrm{~nm}$ was the thickness of the layer of surface chains, and $X$ was the crystallinity index.
The $\mathrm{I}_{\alpha}$ and $\mathrm{I}_{\beta}$ allomorphs content of cellulose was calculated from the relative peak heights of the deconvoluted $\mathrm{C}-4$ region of interior crystalline cellulose.

\section{Wide angle $X$-ray diffractometry (XRD)}

X-ray diffractograms were obtained with a Philips PW1240 with Bragg Brentano geometry $\theta-2 \theta$ with an anticathode of $\mathrm{Cu}$ $\left(\mathrm{CuK} \alpha, \lambda=1.5418 \mathrm{~A}^{\circ}\right)$, the voltage of the diffractor was $40 \mathrm{kV}$ and the current intensity was $40 \mathrm{~mA}$. The diffraction patterns were obtained by collecting intensities $\mathrm{I}(2 \theta)$ over the range from $2 \theta=5^{\circ}$ to $2 \theta=40^{\circ}$ at room temperature. The sifted powder was pressed into small slices and placed in a quartz sample holder scanning. For each sample, the resulting intensities at the points $22.4^{\circ} \leq 2 \theta \leq 22.6^{\circ}$ correspond to the relative intensity of the 002 crystallographic plane $\left(\mathrm{I}_{002}\right)$ of cellulose $\mathrm{I}$, and the other at $18^{\circ} \leq 2 \theta \leq 19^{\circ}$, assigned to the amorphous phase intensity $\left(I_{a m}\right)$ were used for the crystallinity index (CrI) calculation according to the Segal et al. (1959):

$$
\operatorname{CrI}(\%)=\frac{I_{002}-I_{a m}}{I_{002}} \times 100
$$

\section{Data analysis}

All the data were analyzed using the one-way analysis test of variance (ANOVA) followed by the Fischer's LSD (last significant difference) test at $\alpha=0.05$ level of significance with EzANOVA software.

\section{RESULTS \\ Cellulose fibers content, morphology and residual hemicelluloses}

The studied hardwood species displayed a cellulose content listed in Table 1. It was noteworthy that $T$. gabonensis was significantly $(\mathrm{p}<0.001)$ less abundant in cellulose while any significant difference was found between $J$. pellegriniana, A. klaineana and T. africana cellulose content ( $>0.05)$. Regarding the morphological structure, the data collected in Table 1 pointed out that $T$. gabonensis, A. klaineana and T. africana 
cellulose fibers width was in the same range $(24.0-24.2 \mu \mathrm{m})$ but larger than $J$. pellegriniana ones $(18.2 \mu \mathrm{m})$. However, the fibers were the longest for $T$. africana while the wood of A. klaineana displayed the shortest cellulose fibers $(624 \mu \mathrm{m})$.

The fibers characterized by optic microscopy exhibited typical hardwood vessel elements within all the cellulose samples (Figure 2). The wood of J. pellegriniana displayed the lowest fibers width (Figure 2c and $2 \mathrm{~d}$ ), and its cellulose trend to bundle in macrofribrils (Figure 2d) whereas those from $T$. gabonensis and T. africana were likely more dispersed in water solution. For all the fibers, the residual neutral sugars content depicted in Table 2 showed evidence of strong domination of glucose ( $>93.8 \%)$.

\section{Supramolecular structure of hardwood native celluloses as determined by FTIR, XRD and ${ }^{13} \mathrm{C}$ CP/MAS NMR}

Figure 3 displayed typical FTIR spectra of cellulose inside with weak intensity bands at $807-808 \mathrm{~cm}^{-1}$ and $760-774 \mathrm{~cm}^{-1}$ from neutral hemicelluloses free from carboxylic or esters groups were observed. Furthermore, diffraction patterns of the pulps (Figure 4) exhibited typical cellulose I form, with characteristic monoclinic lattice of wood cellulose and four crystalline zones assigned to 101, 10-1, 002 and 040 planes. The CrI and $\mathrm{D}_{002}$ values listed in Table 3 pointed out that $J$. pellegriniana (Figure 4b) and T. africana (Figure 4d) exhibited not only the highest content on well-organized crystalline domains, but also the largest crystallite sizes. But, A. klaineana (Figure 4c) displayed the lowest CrI (59\%) while its cellulose crystallite sizes $(3.60 \mu \mathrm{m})$ were in the same range with T. gabonensis ones $(3.61 \mu \mathrm{m})$.

Solid state NMR spectra of those hardwood pulps exhibited characteristic well resolved peaks of cellulose I (Figure 5) for which assignment was depicted in Table 4 . The lack of peak at $170 \mathrm{ppm}$ arising from $\mathrm{C}=\mathrm{O}$ of carboxyl or ester groups of those hardwood hemicelluloses or lignins agreed with that obtained by FTIR. Nevertheless, the residual hemicellulose content displayed in Table 2 showed evidence of xylose, galactose, arabinose and mannose neutral sugars remaining in the studied hardwood cellulose fibers.

The results obtained (Table 3) were in close agreement with those found by XRD. They show clearly that cellulose fibers from T. gabonensis and A. klaineana displayed the lowest crystallinity and crystallite sizes whereas those from J. pellegriniana and $T$. africana exhibited the highest crystallinity and the largest crystallite sizes.

Spectra enhancement of those fibers showed distinctive $\mathrm{I}_{\alpha}$ and $\mathrm{I}_{\beta}$ polymorphism of wood cellulose (Figure 6). It was noteworthy that the $\mathrm{C}-1$ region exhibited characteristic peaks centred at 105.4-105.8 ppm and assigned to the $\mathrm{I}_{\alpha}$ allomorph, paracrystalline cellulose, chains exposed on crystallite surfaces and amorphous cellulose.

A qualitative analysis of the interior crystallite chains (i) of the expanded C-4 region (Figure 6) showed characteristic shoulder of cellulose $\mathrm{I}_{\alpha}$ at 89.9-90.3 ppm while the cellulose $\mathrm{I}_{\beta}$ appeared at $88.6 \mathrm{ppm}$. Furthermore, the data of Table 5 pointed out an inter-species variability regarding the $\mathrm{I}_{\alpha}$ and $\mathrm{I}_{\beta}$ cellulose content, and all the samples exhibited a $\mathrm{I}_{\alpha} / \mathrm{I}_{\beta}<1$ ratio characteristic of hardwoods indeed. It was noted that the cellulose fibers from $T$. gabonensis were the richest in $\mathrm{I}_{\beta}$ (79.25\%) allomorph while those from A. klaineana were the most abundant in cellulose $\mathrm{I}_{\alpha}(42.1 \%)$ as shown in Table 5.

\section{Chemical reactivity and crystalline lattice susceptibility of hardwoods cellulose esterified by succinic anhydride molecule}

The heterogeneous esterification of hardwood celluloses by succinic anhydride diluted in DMF/Py solvent system heated at $120{ }^{\circ} \mathrm{C}$ for $4 \mathrm{~h}$ was presented in Figure 1 . The weight percent gain (WPG) of esterified hardwood celluloses was listed in Table 6 pointed out significant difference $(\mathrm{p}<0.00001)$ between the chemical reactivity of the studied celluloses which increased as follows: $T$. gabonensis >T. africana > J. pellegriniana > 
A. klaineana. The cellulose fibers from $T$. gabonensis $(16.57 \pm 1.11 \%)$ were the most reactive, while those from $A$. klaineana displayed the lowest reactivity with regard to succinic anhydride $(11.85 \pm 0.62 \%)$. It was found that the succinylation decreased the $\mathrm{CrI}$ of cellulose esters as follows: T. africana $>T$. gabonensis $\approx$. pellegriniana > A. klaineana so that the $\mathrm{D}_{002}$ values were reduced in the range 0.66 to $0.96 \mu \mathrm{m}$ for the most reactive cellulose fibers while that decrease was only of $0.36 \mu \mathrm{m}$ for the less reactive A. klaineana cellulose fibers (Table 6).

Table 1: Tropical hardwoods cellulose content, fibers length and width determined by the MORFI® apparatus.

\begin{tabular}{lccc}
\hline \multicolumn{1}{c}{ Cellulose type fibers } & Content $(\boldsymbol{\%})^{\mathbf{a}}$ & Length $(\boldsymbol{\mu m})$ & Width $(\boldsymbol{\mu m})$ \\
\hline T. gabonensis & $38.9 \pm 01.7^{\mathrm{b}}$ & 700 & 24.0 \\
J. pellegriniana & $51.6 \pm 03.1^{\mathrm{c}}$ & 717 & 18.6 \\
A. Klaineana & $47.9 \pm 01.0^{\mathrm{c}}$ & 624 & 24.2 \\
T. africana & $48.4 \pm 02.6^{\mathrm{c}}$ & 769 & 24.2 \\
\hline
\end{tabular}

Means with the same letter are not statistically different at $\alpha=0.05$ level of significant.

a: Mean \pm S.D. $(n=3)$.
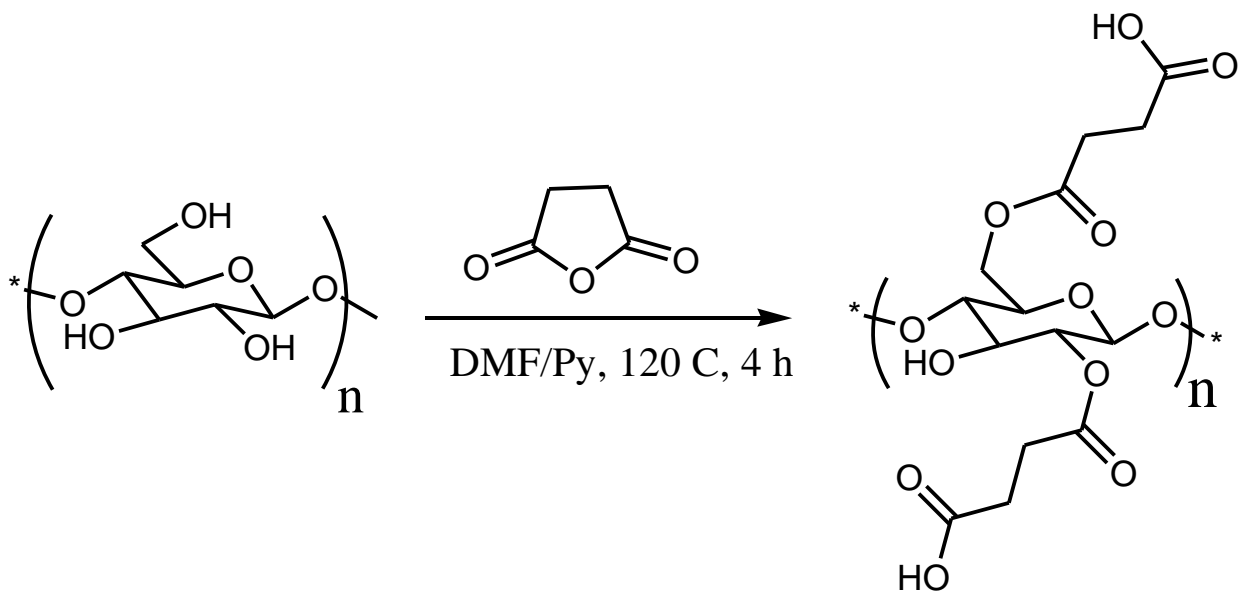

Figure 1: Esterification of hardwood cellulose fibers by succinic anhydride molecule in $\mathrm{N}, \mathrm{N}-$ dimethylformamide (DMF) and pyridine (Py) at $120^{\circ} \mathrm{C}$ for 4 hours.
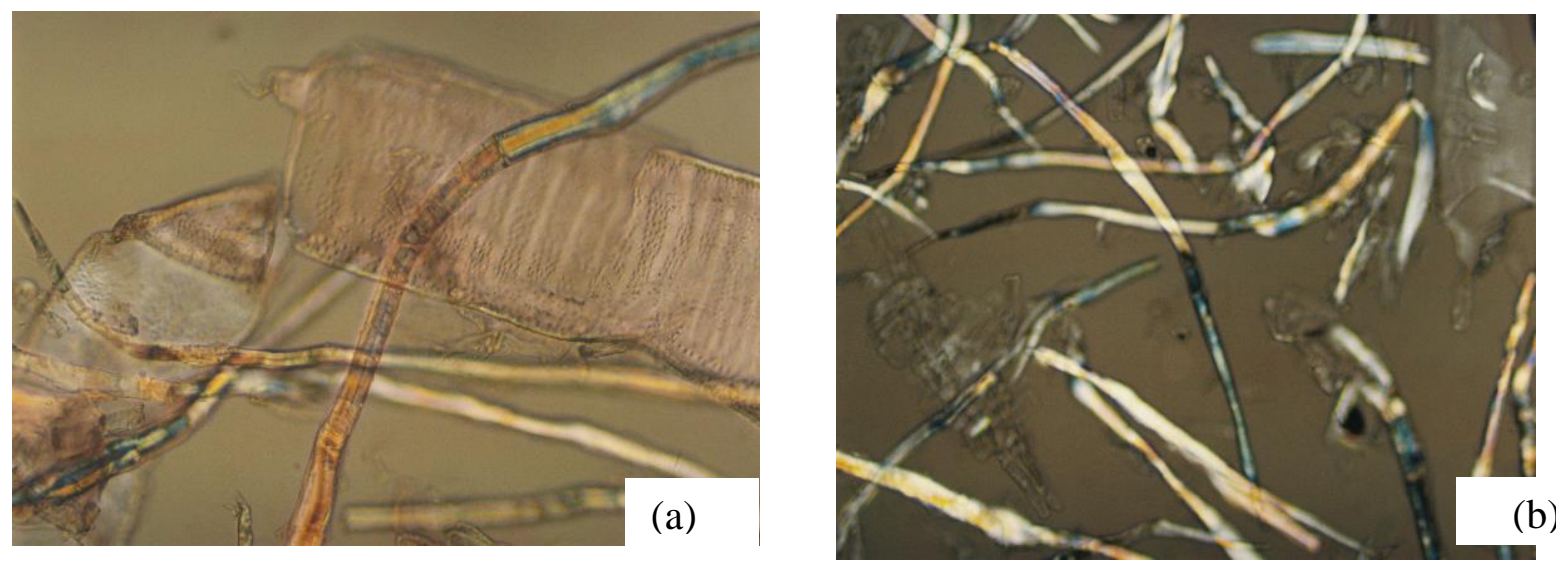

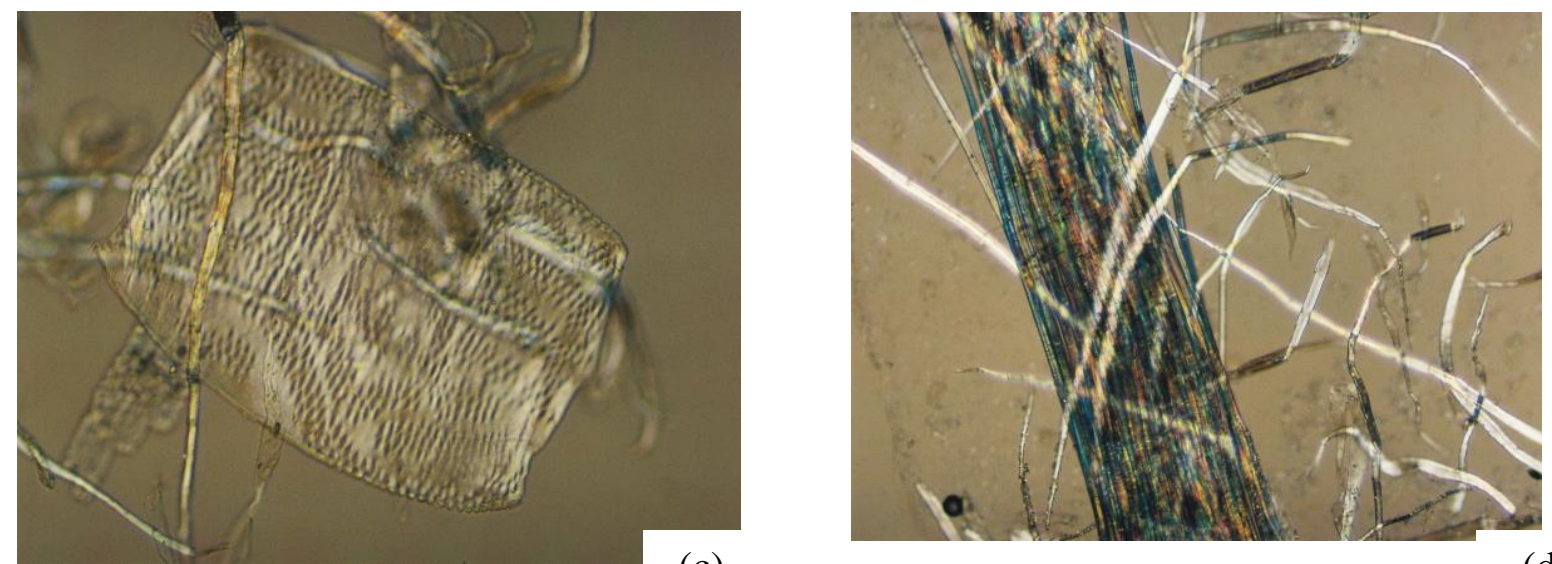

(c)

(d)

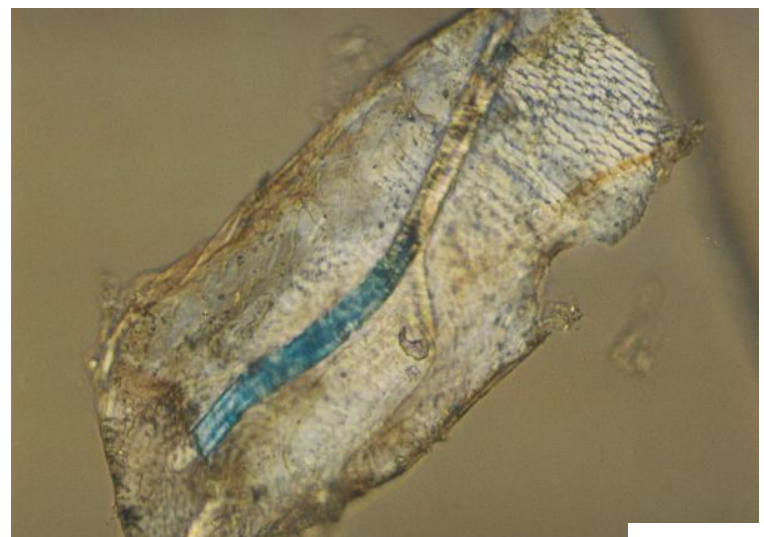

(e)

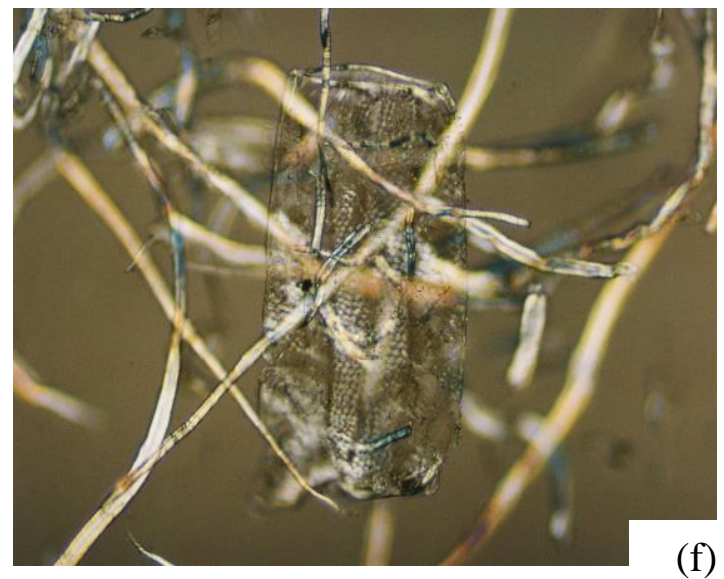

Figure 2: Micrographs of T. gabonensis (a, b), J. pellegriniana (c, d) and T. africana (e, f) cellulose fibers with vessel elements $(\mathrm{Gx} 40)$. A. klaineana were not shown because the fibers were aggregated and completely hidden by unusable vessels texture.

Table 2: Residual hemicelluloses content, released by acid hydrolysis of tropical hardwood cellulose fibers.

\begin{tabular}{lccccc}
\hline Cellulose type fibers & $\begin{array}{c}\text { Glucose } \\
(\boldsymbol{\%})\end{array}$ & $\begin{array}{c}\text { Xylose } \\
(\boldsymbol{\%})\end{array}$ & $\begin{array}{c}\text { Galactose } \\
(\boldsymbol{\%})\end{array}$ & $\begin{array}{c}\text { Arabinose } \\
(\boldsymbol{\%})\end{array}$ & $\begin{array}{c}\text { Mannose } \\
(\boldsymbol{\%})\end{array}$ \\
\hline T. gabonensis & 97.1 & 1.9 & 0.6 & 0.0 & 0.4 \\
\hline J. pellegriniana & 94.5 & 1.3 & 0.3 & 0.1 & 3.8 \\
\hline A. klaineana & 93.8 & 1.6 & 0.4 & 0.0 & 4.5 \\
\hline T. africana & 97.5 & 1.8 & 0.1 & 0.1 & 0.5 \\
\hline
\end{tabular}




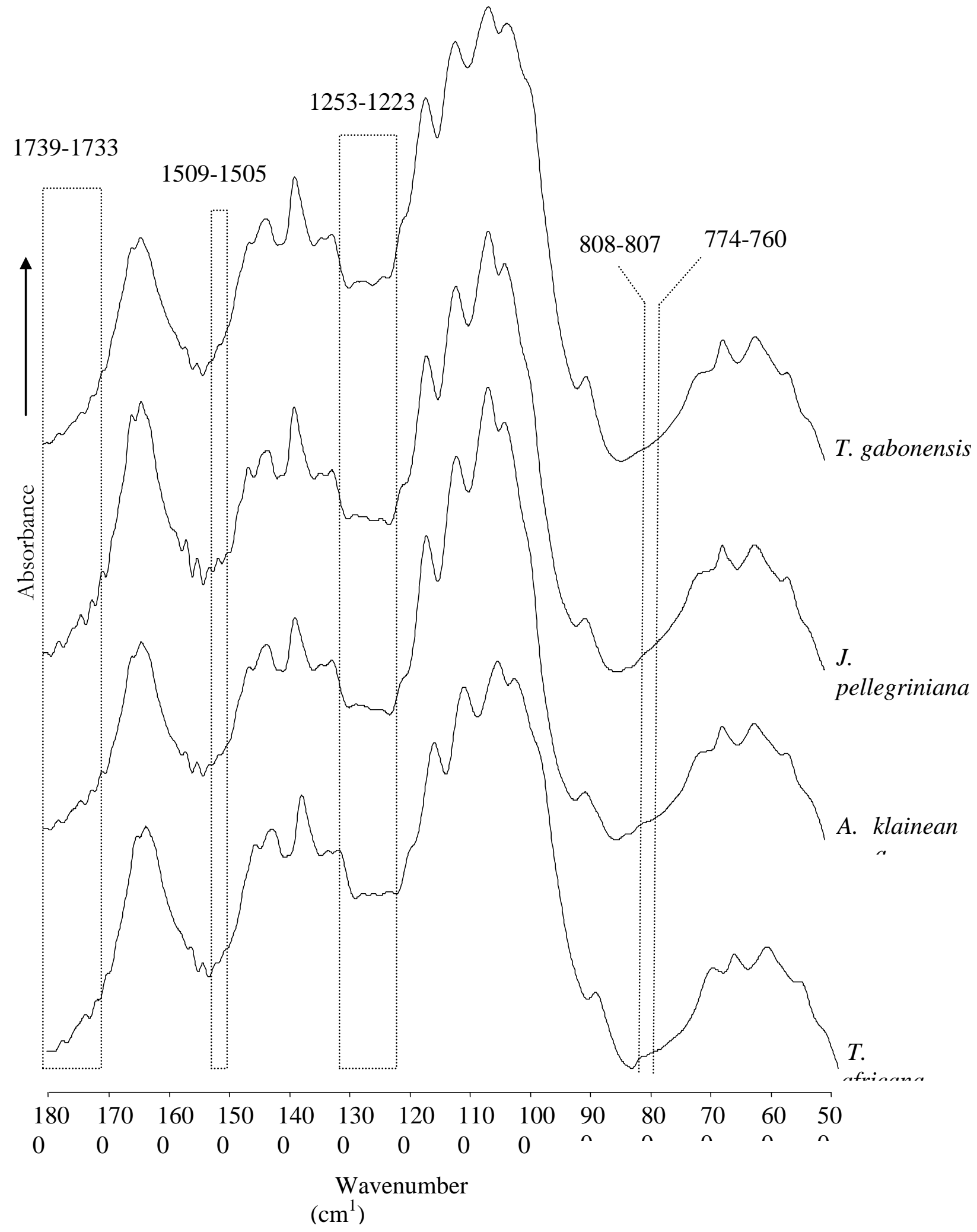

Figure 3: FTIR spectra of tropical hardwood cellulose fibers in the range $1800-500 \mathrm{~cm}^{-1}$. 

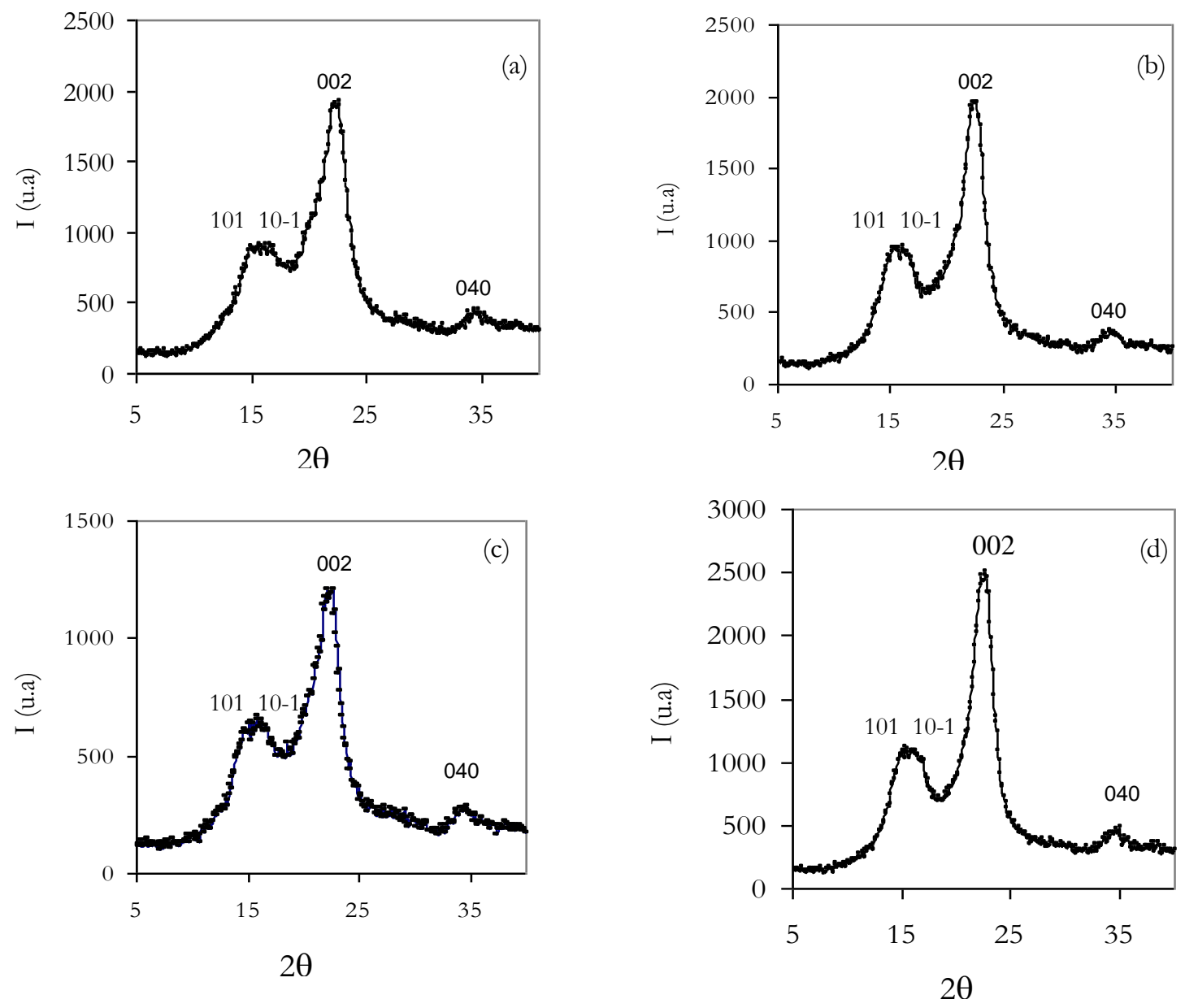

Figure 4: X-ray diffractogram patterns of unesterified T. gabonensis (a), J. pellegriniana (b), A. klaineana (c) and T. africana (d) cellulose fibers.

Table 3: Crystallinity index $(\mathrm{CrI})$, full width at half maximum $\left(\beta_{002}\right)$, diffraction angle $\left(2 \theta_{002}\right)$ and crystallites size $\left(\mathrm{D}_{002}\right)$ in the direction perpendicular to the 002 crystallographic plane of unesterified cellulose fibers determined by XRD and crystallinity index (X) and crystallite size (L) of hardwood cellulose fibers calculated by ${ }^{13} \mathrm{C} \mathrm{CP} / \mathrm{MAS}$ NMR.

\begin{tabular}{|c|c|c|c|c|c|c|}
\hline \multirow{3}{*}{$\begin{array}{c}\text { Cellulose type } \\
\text { fibers }\end{array}$} & \multicolumn{6}{|c|}{ Crystallinity index } \\
\hline & \multicolumn{4}{|c|}{ XRD } & \multirow{2}{*}{$\begin{array}{c}{ }^{13} \mathrm{C} \mathrm{CP} / \mathrm{MAS} \\
\boldsymbol{\%} \\
(\%)\end{array}$} & \multirow{2}{*}{$\begin{array}{c}\text { NMR } \\
L \\
(\mathbf{n m})\end{array}$} \\
\hline & $\begin{array}{c}\beta_{002} \\
(\mathbf{d e g})\end{array}$ & $\begin{array}{l}2 \theta_{002} \\
(\mathrm{deg})\end{array}$ & $\begin{array}{l}\mathrm{D}_{002} \\
(\mathrm{~nm})\end{array}$ & $\begin{array}{l}\text { CrI } \\
(\%)\end{array}$ & & \\
\hline T. gabonensis & 2.34 & 22.5 & 3.61 & 62 & 39.3 & 3.1 \\
\hline J. pellegriniana & 1.87 & 22.6 & 4.50 & 68 & 44.8 & 3.4 \\
\hline A. klaineana & 2.38 & 22.4 & 3.60 & 59 & 38.2 & 2.9 \\
\hline T. africana & 2.02 & 22.6 & 4.20 & 71 & 45.2 & 3.5 \\
\hline
\end{tabular}


Table 4: Chemical shift $(\delta)$ and peaks assignment of tropical hardwood cellulose fibers as determined by ${ }^{13} \mathrm{C}$ CP/MAS NMR referred to (Atalla and Van der Hart, 1984b; Fochera et al., 2001; Maunu et al., 2000; Newman et al., 1993; Newman, 1994, 1997; Newman and Redgwell, 2002; Pu et al., 2006).

\begin{tabular}{|c|c|c|c|c|}
\hline $\begin{array}{l}\text { T. gabonensis } \\
\delta(\mathrm{ppm})\end{array}$ & $\begin{array}{c}\text { J. pellegriniana } \\
\delta(\mathrm{ppm})\end{array}$ & $\begin{array}{l}\text { A. klaineana } \\
\delta(\mathrm{ppm})\end{array}$ & $\begin{array}{l}\text { T. africana } \\
\delta(\mathrm{ppm})\end{array}$ & Peaks assignment \\
\hline 105.4 & 105.5 & 105.8 & 105.4 & $\begin{array}{l}\text { C-1 of crystal interiors, } \\
\text { paracristalline chains, amorphous } \\
\text { cellulose. }\end{array}$ \\
\hline 89.4 & 89.2 & 89.2 & 89.3 & $\begin{array}{l}\text { C-4 of crystal interiors and } \\
\text { paracrystalline chains. }\end{array}$ \\
\hline 84.4 & 84.5 & 84.2 & 84.4 & $\begin{array}{l}\text { C-4 of chains exposed on crystal } \\
\text { surfaces plus amorphous } \\
\text { cellulose } \quad \text { and } \\
\text { hemicellulose chains. }\end{array}$ \\
\hline 75.4 & 75.2 & 75.2 & 75.4 & $\begin{array}{l}\text { C-2, C-3 and C- } 5 \text { of cellulose or } \\
\text { residual hemicelluloses. }\end{array}$ \\
\hline 73.2 & 73.1 & 73.3 & 73.2 & \\
\hline 65.6 & 65.4 & 65.6 & 65.5 & $\begin{array}{l}\text { C- } 6 \text { of crystal interiors and } \\
\text { paracrystalline chains. }\end{array}$ \\
\hline 63.2 & 63.4 & 63.2 & 63.2 & $\begin{array}{l}\text { C-6 of chains exposed on crystal } \\
\text { surfaces plus amorphous } \\
\text { cellulose } \quad \text { and } \\
\text { hemicellulose chains }\end{array}$ \\
\hline
\end{tabular}

Table 5: Cellulose $\mathrm{I}_{\alpha}$ and $\mathrm{I}_{\beta}$ allomorphs calculated from the C-4 region of interior crystallites of solid state NMR celluloses spectra depicted in Figure 6.

\begin{tabular}{|c|c|c|c|c|c|}
\hline \multirow{3}{*}{$\begin{array}{c}\text { Cellulose type } \\
\text { fibers }\end{array}$} & \multicolumn{4}{|c|}{ C-4 } & \multirow[b]{3}{*}{$I_{\alpha} / I_{\beta}$} \\
\hline & \multicolumn{2}{|c|}{$I_{\alpha}$} & \multicolumn{2}{|c|}{$I_{\beta}$} & \\
\hline & $\begin{array}{c}\text { Width } \\
(\mathbf{H z})\end{array}$ & $\%$ & $\begin{array}{r}\text { Width } \\
(\mathbf{H z})\end{array}$ & $\%$ & \\
\hline T. gabonensis & 33.7 & 20.2 & 57.9 & 79.5 & 0.25 \\
\hline J. pellegriniana & 44.1 & 27.7 & 73.6 & 72.3 & 0.38 \\
\hline A. klaineana & 32.5 & 42.1 & 65.0 & 57.9 & 0.73 \\
\hline T. africana & 36.0 & 39.5 & 60.9 & 60.5 & 0.65 \\
\hline
\end{tabular}


Table 6: Weigh percent gain (WPG), crystallinity index (CrI), crystallinity index variation ( $\Delta \mathrm{CrI})$, crystallite size $\left(\mathrm{D}_{002}\right)$ and crystallite size variation $\left(\Delta \mathrm{D}_{002}\right)$ of hardwood cellulose fibers esterified by succinic anhydride molecule.

\begin{tabular}{lccccc}
\hline $\begin{array}{c}\text { Esterified type } \\
\text { cellulose fibers }\end{array}$ & $\begin{array}{c}\text { WPG } \\
(\boldsymbol{\%})^{\mathbf{a}}\end{array}$ & $\begin{array}{c}\text { CrI } \\
(\boldsymbol{\%})\end{array}$ & $\begin{array}{c}\Delta \mathbf{C r I} \\
(\boldsymbol{\%})\end{array}$ & $\begin{array}{c}\mathbf{D}_{\mathbf{0 0 2}} \\
(\boldsymbol{\mu} \mathbf{m})\end{array}$ & $\begin{array}{c}\Delta \mathbf{D}_{\mathbf{0 0 2}} \\
(\boldsymbol{\mu \mathbf { m } )}\end{array}$ \\
\hline $\begin{array}{l}\text { T. gabonensis } \\
\text { J. pellegriniana }\end{array}$ & $16.57 \pm 1.11^{\mathrm{b}}$ & 54 & 8.00 & 2.77 & 0.84 \\
$\begin{array}{l}\text { A. klaineana } \\
\text { T. africana }\end{array}$ & $11.85 \pm 0.62^{\mathrm{d}}$ & 57 & 2.00 & 3.44 & 0.36 \\
& $14.16 \pm 0.67^{\mathrm{e}}$ & 60 & 10.0 & 3.54 & 0.66 \\
\hline
\end{tabular}

Means with the same letter are not statistically different at $\alpha=0.05$ level of significant.

${ }^{\mathrm{a}}$ : Mean \pm S.D. $(n=6)$

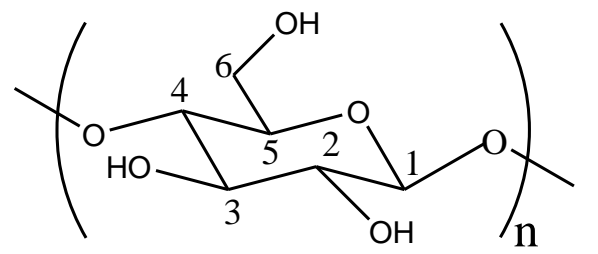

$\mathrm{C}_{2} \mathrm{C}_{3}$

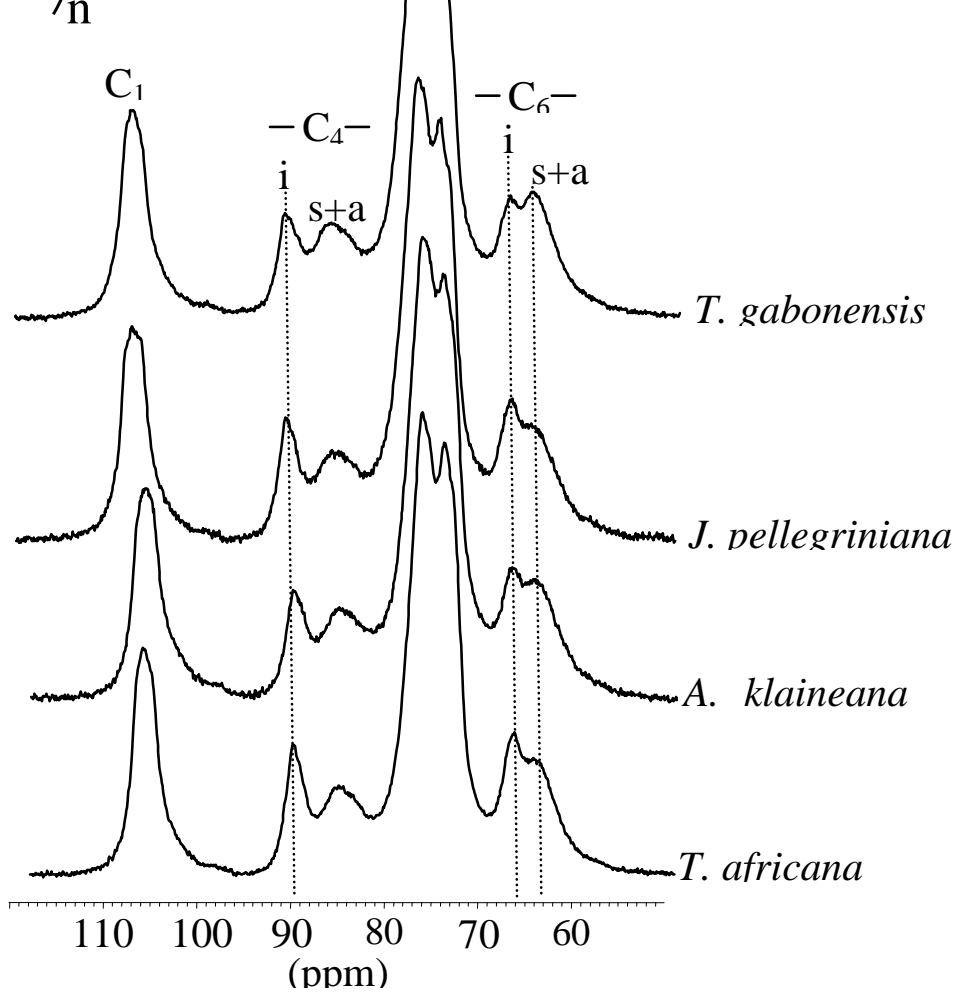

Figure 5: ${ }^{13} \mathrm{C}$ CP/MAS NMR spectra of unesterified tropical hardwood cellulose fibers. (i): chains of crystal interior cellulose. ( $\mathrm{s}+\mathrm{a})$ : chains exposed on crystal surface plus amorphous cellulose. 


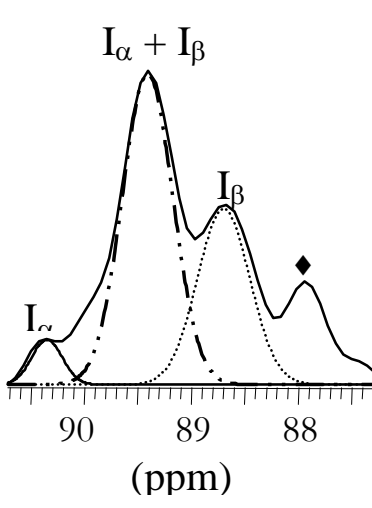

(a)

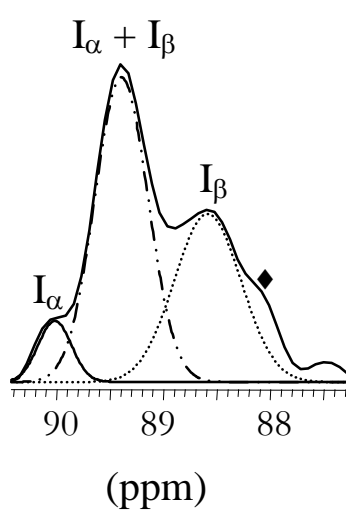

(b)

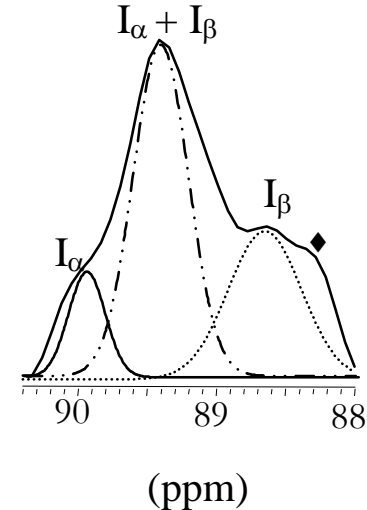

(c)

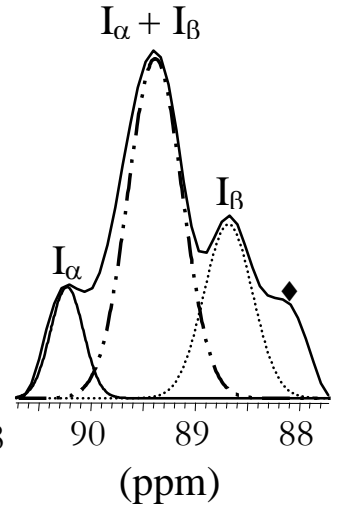

(d)

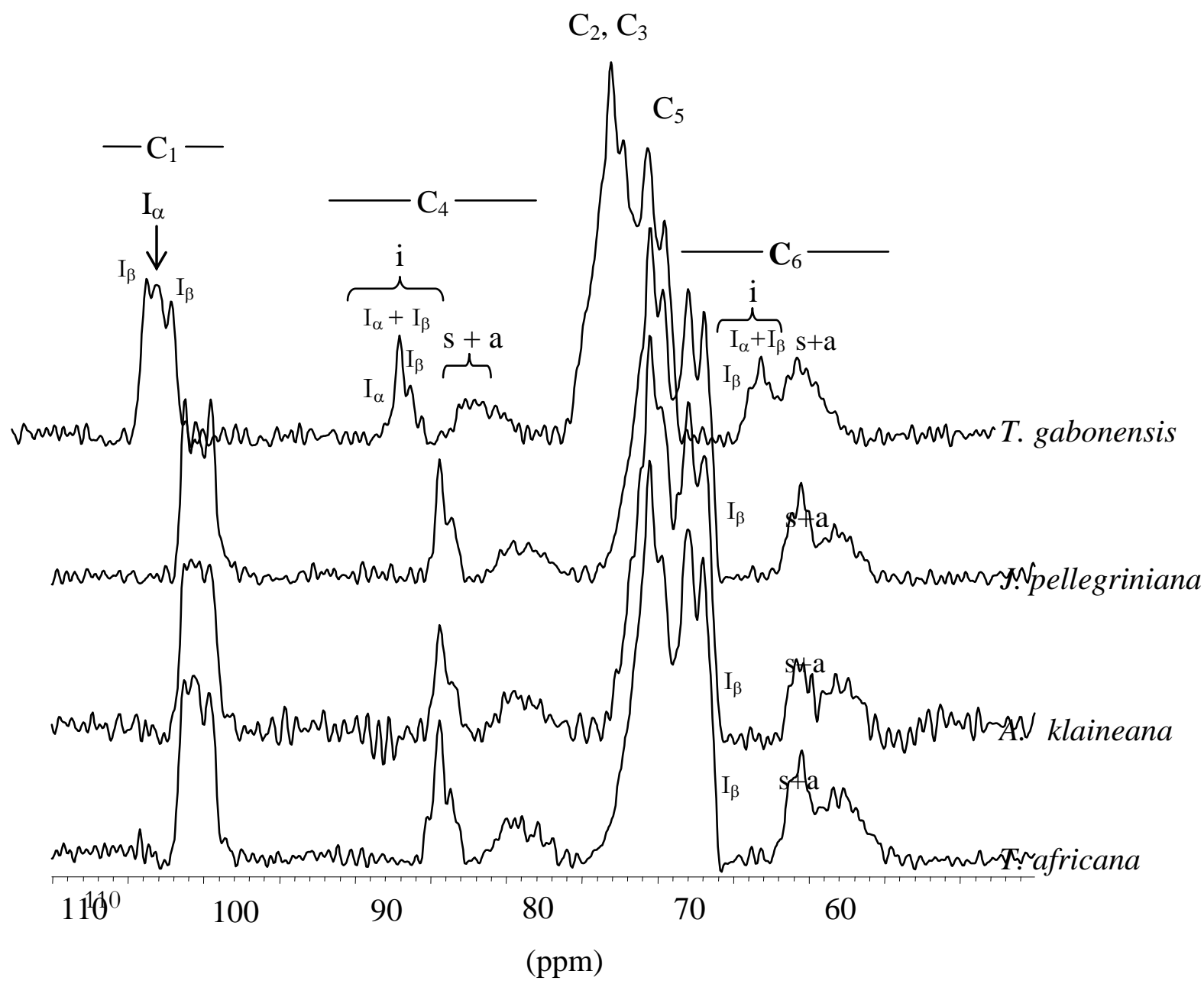

Figure 6: In the top, a portion of baseline corrected and deconvoluted spectra of the C-4 region of signals assigned to the interior chains of unesterified T. gabonensis (a), J. pellegriniana (b), A. klaineana (c) and T. africana (d) cellulose fibers respectively, derived from the spectra enhanced (bottom). (i): chains of crystal interior cellulose chains. (s+a): chains exposed on crystal surfaces plus amorphous cellulose. $(\bullet)$ : Noise. 


\section{DISCUSSION}

The cellulose content listed in Table 1 showed that $T$. gabonensis displayed the lowest one while that exhibited by $A$. klaineana's wood $(47.9 \pm 01.0)$ was close to that previously published by Savard et al. (1960), Lal et al. (1977) and Minkuè M'Eny (2000) who found $47.9 \%, 47.8 \%$ and $50.3 \pm 0.7 \%$ respectively. In addition, the cellulose fibers length we found for $A$. klaineana was accordingly shorter than its corresponding cellulose-hemicellulose complex studied by Richter and Dallwitz (2000), Medzegue (2007) and Safou-Tchiama et al. (2007) who found respective fibers length of $635-1810 \mu \mathrm{m}, 820-1160 \mu \mathrm{m}$ and 682 $\mu \mathrm{m}$ for unground samples.

FTIR spectra of all the fibers (Figure 3) did not show typical bands of lignin at 1510 $1508 \mathrm{~cm}^{-1}$ and $1268-1217 \mathrm{~cm}^{-1}$; even less that associated with the aromatic ring $\mathrm{C}-\mathrm{O}$ stretching mode of lignin at $1595 \mathrm{~cm}^{-1}$ previously observed in those hardwood holocelluloses (Safou-Tchiama et al., 2007). That result supported the extraction of lignin in very high extent inside the cellulose fibers. It was obvious that the peculiar $\mathrm{C}=\mathrm{O}$ stretching band at $1735-1733 \mathrm{~cm}^{-1}$ assigned to ester or carboxylic acid groups from hemicelluloses or lignin (Safou-Tchiama et al., 2007; 2017) was not present in the hardwood celluloses spectra (Figure 3). The lack of carbonyl groups in these celluloses suggested that acid or ester groups from hemicelluloses like glucuronic acids previously found in A. klaineana's heartwood (Safou-Tchiama et al., 2016) have been extensively removed from the cellulose fibers. However, weak intensity bands at 807-808 $\mathrm{cm}^{-1}$ and $760-774 \mathrm{~cm}^{-1}$ assigned to glucomannans (Hult et al., 2003) and xylan $\alpha-$ type glycosidic links (Kacurakova et al., 1998) corroborated that neutral hemicelluloses free from carboxylic or esters groups remained incrusted in some extent within those cellulose fibers. Xylose was the major neutral sugar incrusted in the pulps of $T$. gabonensis and $T$. africana while mannose was more abundant in J. pellegriniana and A. klaineana cellulose fibers (Table 2). Furthermore, the dominating glucose content of those hardwood carbohydrates suggested that xylans, galactans and mannans were trapped within the structure rather than associated with cellulose as claimed for other cellulose source of low hemicelluloses content (Whitney et al., 1998).

The occurrence of such residual hemicelluloses which were previously observed in Populus wood pulp and cotton fibers should overlap NMR-signals from C-4, and C-6 region of cellulose, and contribute to the signal intensity of resonances of interest (Foston et al., 2011). Nevertheless, the relatively low amount of residual hemicelluloses in the pulps compared with the cellulose content and the lack of distinctive peak at $101 \mathrm{ppm}$ (Figure 5) assigned to the C1 of hemicelluloses (Liitia et al., 2003) such as mannans (Marchessault et al., 1990), xylans in strong cellulose-xylan interactions (Larsson et al., 1999) or to the galactose C-1 signal at $99.6 \mathrm{ppm}$ (Whitney et al., 1998) allows to calculate the crystallinity index and the crystallite sizes of the cellulose samples by solid state NMR. As a consequence, the shoulders at 104.6-104.5 ppm and 106.3-106.1 ppm should be assigned to $\mathrm{I}_{\beta}$ allomorph (Newman, 1994, 1997); they pointed out relative strength differences supporting the inter-species variability on $\mathrm{I}_{\beta}$ allomorph observed in Table 5.

Concerning the chemical reactivity of the cellulose fibers with succinic anhydride, data collected in Tables 6 showed that $T$. gabonensis and T. africana cellulose fibers displayed significant difference on their esterification through the anhydride moiety. The highest WPG of those cellulose esters $(16.57 \pm 1.11$ and $14.16 \pm 0.67 \%$, respectively) suggested a better swelling efficiency of the solvent system (DMF/Py) for T. gabonensis and T. africana cellulose fibers. That would render their $(\mathrm{O}-2) \mathrm{H}, \mathrm{O}-3(\mathrm{H})$ and (O-6) H hydroxyl groups more accessible to succinic anhydride. The trend of those two hardwood cell walls for having a good swelling efficiency through DMF/Py was previously observed for their wood blocks treated in similar conditions (Safou-Tchiama et al., 2007). In addition, the access of succinic anhydride to the hydroxyl groups of $T$. gabonensis and T. africana cellulose should have been facilitated by the strong ability of those two hardwood pulps to disperse in polar media as shown in Figure 2a,b and Figure 
2d,e. Nevertheless, the CrI and $X$ values of unesterified cellulose showed abundance of amorphous phase and chains exposed on crystals surface of $T$. gabonensis's cellulose (Table 3). The later should have been strongly swelled by DMF/Py, increasing like this the esterification of its cellulose in higher extent than $T$. africana; which should highlight the strong swelling coefficient of succinylated $T$. gabonensis wood blocks (Safou-Tchiama et al., 2007).

However, the reactivity of $J$. pellegriniana's cellulose displayed significant difference with $T$. gabonensis and T. africana ones, whereas the cellulose from $J$. pellegriniana displayed a low reactivity regarding succinic anhydride compared with $T$. gabonensis and T. africana. That weak esterification may result not only from its small fibers width $(18.6 \mu \mathrm{m})$ as depicted in Table 1, but also from the tend of $J$. pellegriniana's cellulose to bundle in macrofibrils (Figure $2 \mathrm{c}, \mathrm{d}$ ), that should limit the access of succinic anhydride to the hydroxyl groups of its cellulose fibers. Nevertheless, the reactivity of J. pellegriniana and A. klaineana celluloses through succinic anhydride presented significant difference (Table 6).

Despite that A. klaineana displayed the highest content in amorphous cellulose (Table 3) and one of the largest fibers width (Table 1), its cellulose was the less esterified (Table 6). That should be explained by the trend of short A. klaineana cellulose fibers to agglomerate in aqueous medium as observed in MORFI ${ }^{\circledR}$ and optic microscopy (not shown). Such a capability of short fibers to aggregate was previously described for other natural fibers (Mwaikambo et al., 2002) and would like this worsen the esterification of $A$. klaineana's cellulose by succinic anhydride.

For all the cellulose esters obtained, XRD showed a broadening of the 002 plane (Figure 7). The subsequent $\mathrm{CrI}$ and $\mathrm{D}_{002}$ decrease (Table 6) suggested that esterification occurred not only inside the amorphous cellulose, but also in the chains of crystal domains. Furthermore, the extent of chains esterified in the crystalline zone was accordingly the highest for the most reactive $T$. gabonensis, J. pellegriniana and $T$. africana cellulose fibers which exhibited the strongest reduction of $\mathrm{CrI}$ and $\mathrm{D}_{002}$. The crystalline domains of short and aggregated $A$. klaineana cellulose fibers were weakly esterified and showed the lowest $\mathrm{CrI}$ and $\mathrm{D}_{002}$ decrease as well (Table 6). That low reduction of crystallinity should be connected to the poor swelling coefficient of those short and aggregated fibers through DMF/Py as pointed out by the succinylated A. klaineana's wood sawdust and wood blocks (Safou-Tchiama et al., 2007).

The evidence of grafted succinic anhydride onto those hardwood cellulose fibers was corroborated by Solid state NMR spectra (Figure 8 ) which showed typical peak at $170 \mathrm{ppm}$ assigned to the $\underline{\mathrm{C}}=\mathrm{O}$ of esters and pendant carboxylic acid groups of succinylated cellulose. The corresponding $-\left(\mathrm{CH}_{2}\right)_{2}-$ grafted succinic moiety alkyl chain appeared at $29 \mathrm{ppm}$. The reduction of the peaks at 75.4-75.2 ppm for $\mathrm{O}-2(\mathrm{H})$ and $\mathrm{O}-$ $3(\mathrm{H})$ and those at $63.4-63.2 \mathrm{ppm}$ for $\mathrm{O}-6(\mathrm{H})$ suggested that hydroxyl groups of cellulose and residual hemicellulose were esterified. On the other hand, the occurrence of a broad at 103-100 ppm assigned to C-1 of esterified anhydroglucose units (Berlioz, 2007) corroborated the esterification of cellulose. Their counterpart peaks appeared at $88.9 \mathrm{ppm}$ (Figure 8a' and 8d') in the C-4 region for the most reactive cellulose fibers of $T$. gabonensis and $T$. africana. Those peaks were assigned to partially substituted ester cellulose rings in esterified radiata pine, western hemlock (Jandura et al., 2000), Valonia (Yamamoto et al., 2006) or cotton cellulose (Doyle et al., 1986). Their presence indicated that some interior crystal chains of $T$. gabonensis and $T$. africana celluloses were esterified. On the other hand, the reduction of the signal strength of peaks at 89.4-89.2 ppm for all the cellulose esters (Figure 8) supported that interior crystallite chains of $J$. pellegriniana and $A$. klaineana celluloses were esterified in some extent.

Nevertheless, the dramatic decrease of the peaks at 63.4-63.2 ppm (Figure 8) of $\mathrm{O}-6(\mathrm{H})$ of amorphous cellulose and chains exposed on crystal surface which contrasted with the small signal strength reduction of interior crystal peaks centred at 89.2-89.4 ppm and 65.4-65.6 ppm (Figure 8) supported that the heterogeneous esterification of those 
hardwood cellulose fibers was mainly restricted to chains exposed on crystals surface and amorphous cellulose indeed.

Despite that interior crystallite chains centred at 89.2-89.4 ppm of those cellulose esters decreased slightly, a qualitative analysis of the C-4 region of spectra enhanced (Figure $8 \mathrm{a}$ ', 8b', and 8c') didn't show significant changes on the signal strengths of $T$. gabonensis, J. pellegriniana and A. klaineana $\mathrm{I}_{\alpha}$ and $\mathrm{I}_{\beta}$ allomorphs.

However, the $\mathrm{I}_{\alpha}$ and $\mathrm{I}_{\beta}$ allomorphs of $T$. africana cellulose ester displayed an obvious decrease of their signal strength (Figure 8d') without any evidence of preferential esterification of $\mathrm{I}_{\alpha}$ over the more stable $\mathrm{I}_{\beta}$ allomorph. Although similar lack of difference on $\mathrm{I}_{\alpha}$ and $\mathrm{I}_{\beta}$ allomorphs reactivity was reported for cellulose oxidized by TEMPO (Carlsson et al., 2015), the present results underlined the morphological (Tjeerdsma and Militz, 2005) and the crystalline structure variability control on the chemical reactivity of cellulose with succinic anhydride in heterogeneous phase.

At least, the chemical reactivity of those hardwood celluloses may be discussed in the basis of $(\mathrm{O}-6) \mathrm{H}$ from additional peaks of $\mathrm{I}_{\alpha}$ and $\mathrm{I}_{\beta}$ allomorphs and the shoulder of $\mathrm{I}_{\beta}$ allomorph of crystal interior cellulose arising in the range 66.3-66.01 ppm region (Figure 6 and 8). But, the occurrence of residual xylans and mannans appearing respectively at 64.2 ppm (Simmons et al., 2016) and 62.4 ppm (Marchessault et al., 1990) and the signal background noise in this area render difficult an accurate investigation of the gauchegauche ( $g g)$ and gauche-trans ( $g t)$ conformation of the reactive hydroxyl groups from the C- 6 of chains exposed on crystals surface or amorphous cellulose which appear in the range 63.1-63.4 ppm (Newman and Davidson, 2004).

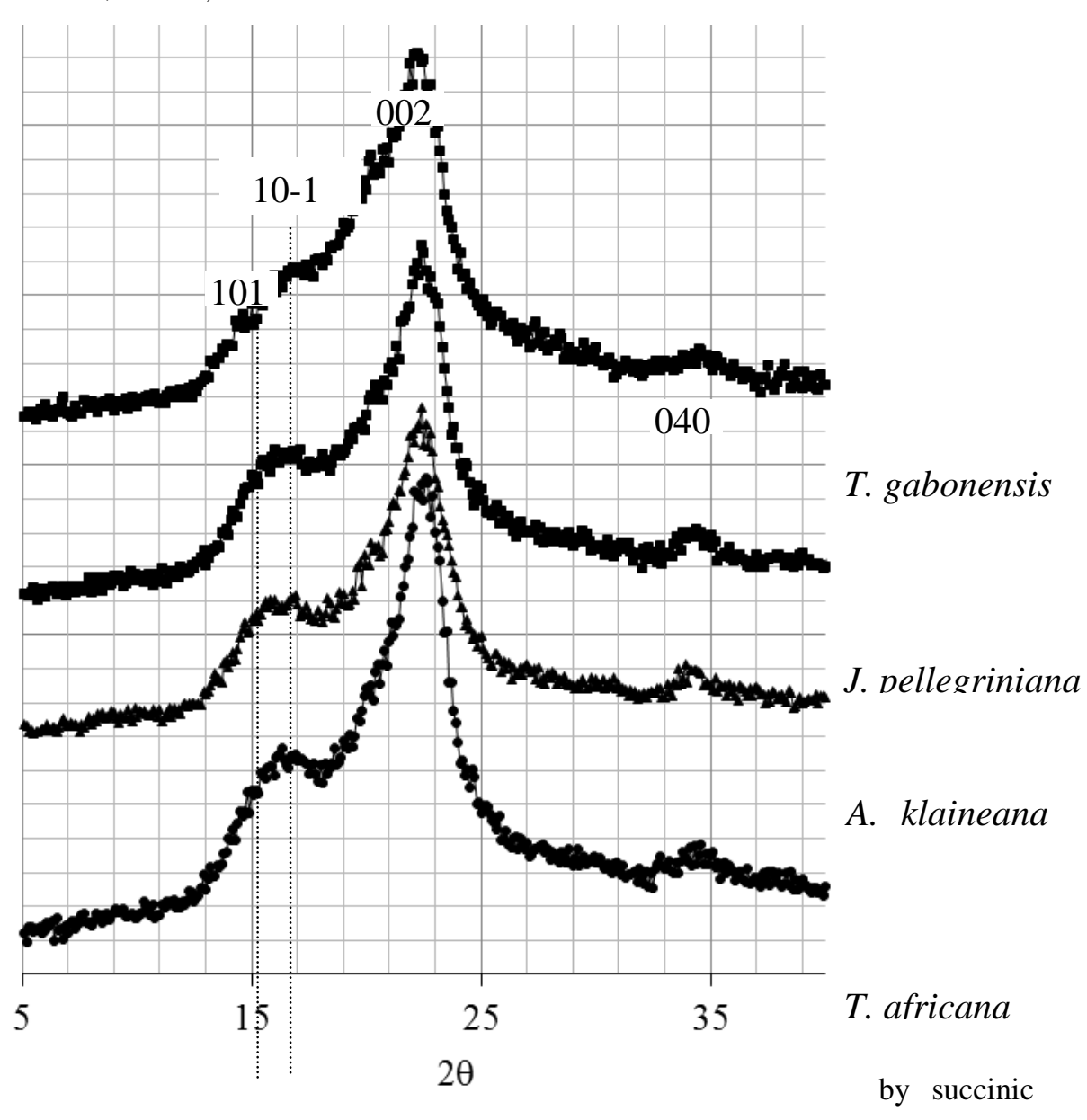

Figure7: X-ras anhydride. 

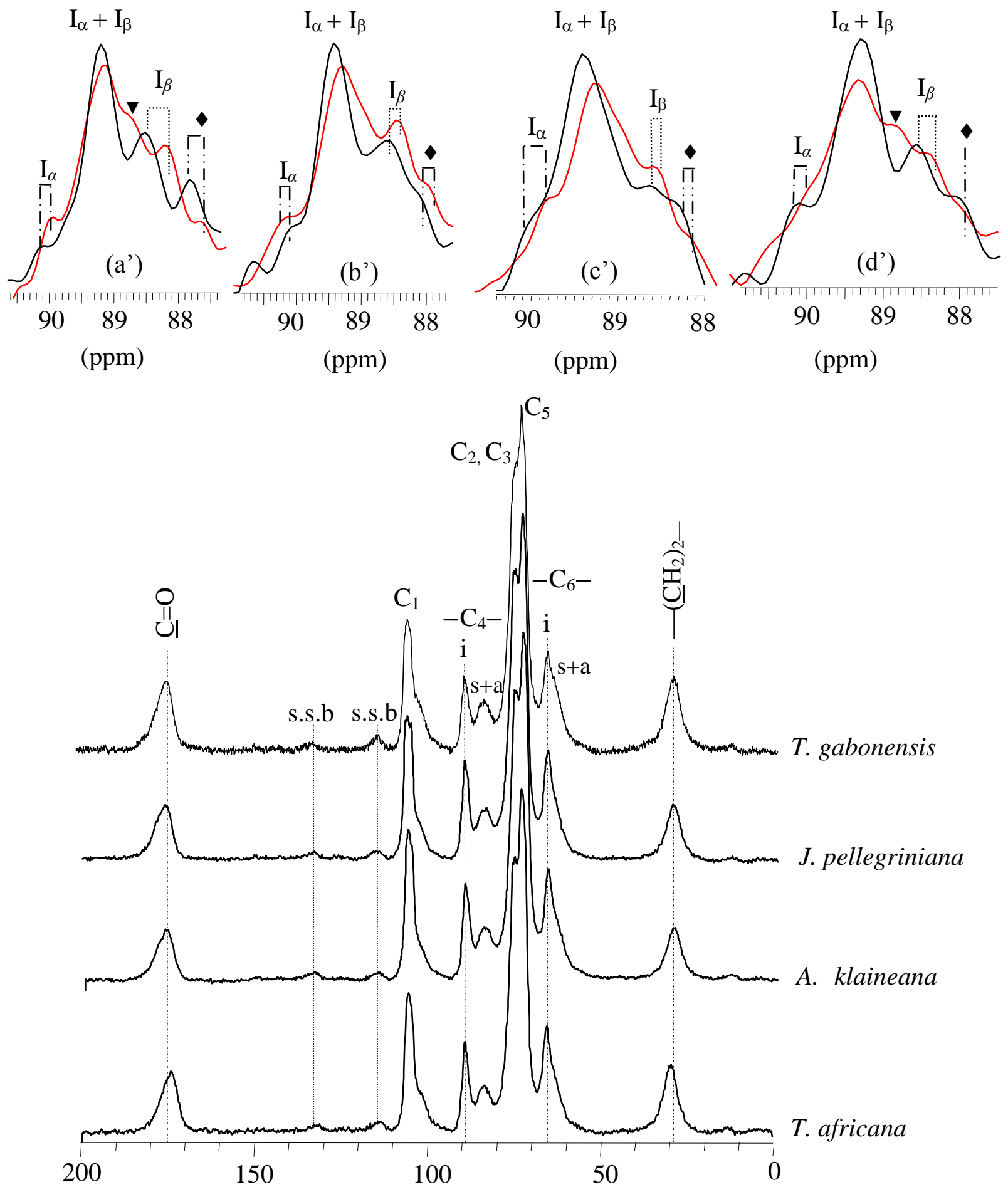

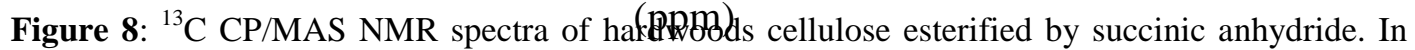
the top, a portion of spectra enhanced for the C-4 region of interior crystallites chains of unesterified T. gabonensis (a'), J. pellegriniana (b'), A. klaineana (c') and T. africana (d') (in black) and esterified cellulose fibers (in red). The abbreviation "s.s.b" indicates spinning sideband. ( $\boldsymbol{\nabla}$ ) Partially substituted ester cellulose rings. $(\bullet)$ : Noise. 


\section{Conclusion}

Investigating the cellulose content from four tropical hardwoods of interest has shown that the heartwood of J. pellegriniana, A. klaineana and $T$. africana were more abundant in cellulose than $T$. gabonensis one. The cellulose extracted from A. klaineana exhibited short and aggregated fibers whereas those from $J$. pellegriniana displayed the smallest fibers width. Their chemical reactivity through succinic anhydride molecule used as model compound for coupling agents like maleate polypropylene showed that the esterification depended strongly on cellulose fibers origin. Nevertheless, the heterogeneous esterification of those celluloses was widely controlled by amorphous cellulose and chains exposed on crystal surfaces, whereas only a few content of interior crystallite chains were succinylated. With the exception of $T$. africana, no significant decrease of $\mathrm{I}_{\alpha}$ and $\mathrm{I}_{\beta}$ allomorph was found. That weak reactivity of interior crystalline chains makes though to a micromechanical stability of the resulting cellulose esters. However, further investigations are necessary to elucidate the micromechanical and the thermal stability of those hardwood cellulose esters in order to understand the final properties of their wood polymer composites.

\section{COMPETING INTERESTS}

The authors declare that they have no competing interests.

\section{AUTHORS' CONTRIBUTIONS}

RST acted as project leading in chemical reactivity of hardwood with succinic anhydride and coupling agent molecules. TAB and SP were members of the project and corrected the paper. SNO, SBMI, ABBA and PSEA were PhD students in wood chemistry who contributed to anatomical analysis and polysaccharides hydrolysis of the woods. BDJ and AGA were scientific directors.

\section{ACKNOWLEDGEMENTS}

The authors thank the Programme de Mobilité Scientifique et Universitaire of l'Agence Universitaire de la Francophonie (AUF) for their financial support. Eric Lebraud of the ICMCB (Institut de Chimie de la Matière Condensée de Bordeaux) and Philippe Négrier of the CPMOH (Centre de Physique Moléculaires et Ondes Hertziennes) of Bordeaux University are thanked for their support on X-ray diffraction analysis. Michel Pétraud of the Centre d'Etude Structurale et d'Analyse des Molécules Organiques (CESAMO) of Bordeaux University is thanked for solid state NMR acquisition and analysis. Jean-Michel Lasnier, Eric Virol, Bernadette Guillabert and Mélanie Bousquet of the LCPO (Laboratoire de Chimie des Polymères Organiques) of Bordeaux University are thanked for the morphological analysis and the neutral sugars content determination.

\section{REFERENCES}

Adamafio NA, Obodai M, Brimpong B. 2009. Solid state fermentation of maize (zea mays) cob by pleurotus ostreatus strain EM-1: biopolymer profiles and cellulose degradability. Int. J. Biol. Chem. Sci., 3(6): 1459-1466. DOI : http://ajol.info/index.php/ijbcs

Aimin T, Hongwei Z, Gang C, Guohui X, Wenzhi L. 2005. Influence of ultrasound treatment on accessibility and regioselective oxidation reactivity of cellulose. Ultra. Sonochem., 12: 467472. DOI https://doi.org/10.1016/j.ultsonch.2004. 07.003

Atalla RH, Van der Hart DL. 1984a. Native Cellulose: a composite of two distinct crystal forms. Science, 223(4623): 283285.

DOI:

https://doi.org/10.1126/science.223.4633 .283

Atalla RH, Van der Hart DL. 1984b. Studies of microstructure in native celluloses using solid-state ${ }^{13} \mathrm{C}$ NMR. Macromol., 17(8):1465-1472. DOI https://doi.org/10.1021/ma00138a009 
Atalla RH. 1987. The structure of cellulose. In ACS symposium series, ACS (ed). American Chemical Society: Washington, DC; 340.

Bakre LG, Jaiyeoba KT. 2009. Studies on the physicochemical properties of Abelmuscus esculentus L. (Okra) pods-a potential tablet excipient. Int. J. Biol. Chem. Sci., 3(3): 448-456. DOI: https://www.ajol.info/index.php/ijbcs/art icle/view/45345/28827

Berlioz S. 2007. Etude de l'estérification de la cellulose par une synthèse sans solvant. Application aux matériaux nanocomposites. Thèse de doctorat, Université Joseph-Fourier- Grenoble I, p.154. https://tel.archives-ouvertes.fr/tel$00266895 \mathrm{v} 2$

Carlsson DO, Lindh J, Strømme M, Mihranyan A. 2015. Susceptibility of $I_{\alpha}$ and $\mathrm{I}_{\beta}$ dominated cellulose to TEMPOmediated oxidation. Biomacromol., 16(5): $\quad$ 1643-1649. DOI: https://doi.org/10.1021/acs.biomac. 5 b00274

Davis M, Baker J, Rignall T, Himmel M. 2004. Changes in cellulose morphology of pretreated yellow poplar during enzymatic hydrolysis. In $26^{\text {th }}$ Symposium on biotechnology for fuels and chemicals. Chattanooga choo choo: Chattanooga, TN, USA. May; 9-12.

Doyle S, Pethrick R, Harris RK, Lane JM, Packer KJ. 1986. ${ }^{13} \mathrm{C}$ nuclear magnetic resonance studied of cellulose acetate in the solution and solid states. Polymer, 27: 19-24. DOI: https://doi.org/10.1016/00323861(86)90351-4

Eze SO, Igwe JC, Dipo D. 2013. Effect of particle size on adsorption of heavy metals using chemically modified and unmodified fluted pumpkin and broadleafed pumpkin pods. Int. J. Biol. Chem. Sci., 7(2): 852-860. DOI: http://dx.doi.org/10.4314/ijbcs.v7i2.40

Foston MB, Hubbell CA, Ragauskas AJ. 2011. Cellulose isolation methodology for NMR analysis of cellulose ultrastructure. Materials, 4:1985-2002. DOI: https://doi.org/10.3390/ma4111985 Fochera B, Palma MT, Canetti M, Torri G, Cosentinob C, Gastaldia G. 2001. Structural differences between non-wood plant celluloses: evidence from solid state NMR, vibrational spectroscopy and $\mathrm{X}$-ray diffractometry. Ind. Crops and Prod., 13(3): 193-208. DOI : https://doi.org/10.1016/S09266690(00)00077-7

Gardner KH, Blackwell J. 1974. The structure of native cellulose. Biopolym., 13(10):1975-2001. DOI: http://dx.doi.org/10.1002/bip.1974.3601 31005

Gurgel LVA, Karnitz JO, Freitas GRP, Gil LF. 2008. Adsorption of $\mathrm{Cu}(\mathrm{II}), \mathrm{Cd}(\mathrm{II})$, and $\mathrm{Pb}$ (II) from aqueous single metal solutions by cellulose and mercerized cellulose chemically modified with succinic anhydride. Biores. Technol., 99(8):3077-3083. DOI http://dx.doi.org/10.1016/j.biortech.2007 .05 .072

Hadano S, Onimura K, Tsutsumi H, Yamasaki H, Oishi T. 2003. Syntheses of chemicalmodified cellulose obtained from waste pulp. J. Appl. Polym. Sci., 90(8): 20592065.

DOI: http://dx.doi.org/10.1002/app.12807

Habibi Y, Lucia LA,Orlando J. Rojas OJ. 2010. Cellulose nanocrystals: Chemistry, self-assembly, and applications. Chem. Rev., 110(6): 3479 3500.

DOI: http://doi.org/10.1021/cr900339w

Hayashi N, Sugiyama J, Okano T, Ishihara M. 1998. Selective degradation of the cellulose $\mathrm{I}_{\alpha}$ component in Cladophora cellulose with Trichoderma viride cellulase. Carbohydr. Res., 305(1): 109116.

DOI : https://doi.org/10.1016/S00086215(97)00281-4

Hayashi N, Kondo T, Ishihara M. 2005. Enzymatically produced nano-ordered short elements containing cellulose $\mathrm{I}_{\beta}$ crystalline domains. Carbohydr. Polym., 
61(2):

191-197.

DOI : https://doi.org/0.1016/j.carbpol.2005.04. 018

Hult EL, Iversen T, Sugiyama J. 2003. Characterization of the supermolecular structure of cellulose in wood pulp fibres. Cellulose, 10(2): 103-110. DOI: https://doi.org/10.1023/A:1024080700 873

Jandura P, Kokta BV, Riedl B. 2000. Fibrous long-chain organic cellulose esters and their characterization by diffuse reflectance FTIR spectroscopy, solid state CP/MAS ${ }^{13} \mathrm{C} \mathrm{NMR}$, and X-ray diffraction. J. Appl. Polym. Sci., 78(7): 1354-1365.

DOI:

http://dx/doi/org/10.1002/1097-

4628(20001114)78:7<1354::AID-

APP60>3.0.CO;2-V

Kacurakova M, Belton PS, Wilson RH, Hirsch J, Ebringerova A. 1998. Hydration properties of xylan-type structures: an FTIR study of xylooligosaccharides. $J$. Food and Agric., 77(1): 38-44. DOI : http://dx/doi/org/10.1002/(SICI)1097-

0010(199805)77:1<38::AID-

JSFA999>3.0.CO;2-5

Kono H, Yunoki S, Shikano T, Fujiwara M, Erata T, Takai M. 2002. CP/MAS ${ }^{13} \mathrm{C}$ NMR study of cellulose and cellulose derivatives. 1. Complete assignment of the CP/MAS ${ }^{13} \mathrm{C}$ NMR spectrum of the native cellulose. J. Am. Chem. Soc., 124(25): 7506-7511. DOI: http://doi.org/10.1021/ja010704o

Lal NK, Butnaru R, Simionescu C. 1977. Chemical composition and analysis of wood. In Wood Chemistry, Ultrastructure, Reactions, Fengel D, Wegener G. (eds). Walter de Gruyter: New York; 58-62.

Larsson PT, Hult EL, Wickholm K, Pettersson E, Iversen T. 1999. CP/MAS ${ }^{13} \mathrm{C}-\mathrm{NMR}$ spectroscopy applied to structure and interaction studies on cellulose I. Solid State Nucl. Magn. Res., 15(1): 31-40. DOI : https//doi.org/10.1016/S09262040(99)00044-2

Liitiä T, Maunu ST, Hotling B, Tamminen T, Pekkala O, Varhimo A. 2003. Cellulose crystallinity and ordering of hemicelluloses in pine and birch pulps as revealed by solid-state spectroscopic methods. Cellulose, 10(4): 307-316. DOI:

http://doi.org/10.1023/A:10273025268 61

Liu CF, Sun RC, Qin MH, Zhang AP, Ren JL, Xu F, Ye J, Wu SB. 2007. Chemical modification of ultrasound-pretreated sugarcane bagasse with maleic anhydride. Ind. Crops and Prod., 26: 212-219.

DOI: http://doi.org/0.1016/j.indcrop.2007.03.0 07

Liu CF, Zhang AP, Li WY, Sun RC. 2011. Chemical Modification of cellulose with succinic anhydride in ionic liquid with or without catalysts. In Ionic Liquids: Applications and Perspectives, Prof. Alexander Kokorin (ed). InTech Europe: Crotia; 81-94. http://cdn.intechopen.com/pdfs/13723/In TechChemical_modification_of_cellulos e_with_succinic_anhydride_in_ionic_liq uid_with_or_without_catalysts.pdf

Liu R, Yu H, Huang Y. 2013. Structure and morphology of cellulose in wheat straw. Cellulose, $\quad$ 12(1): 25-34. https://link.springer.com/article/10.1007/ s10570-004-0955-8

Marchessault RH, Taylor MG, Winter WT. 1990. ${ }^{13} \mathrm{C}$ CP/MAS NMR spectra of poly- $\beta-\mathrm{D}(1-4)$ mannose: mannan. Can. J. Chem., 68(7): 1192-1195. DOI : https://doi.org/10.1139/v90-184

Maunu ST, Liitiä T, Kauliomäki S., Hortling B, Sundquist J. 2000. ${ }^{13} \mathrm{C}$ CPMAS NMR investigation of cellulose polymorphs in different pulps. Cellulose, 7(2): 147159.

DOI: https://doi.org/10.1023/A:1009200609 482

Medzegue M. 2007. Thèse de doctorat, Université Bordeaux 1, France, pp. 118119.

Minkué M'Eny S. 2000. Etude chimique de substances extractibles d'Okoumé. Mémoire de Master, Université Laval, Canada, p. 54. 
Mwaikambo LY, Ansell MP. 2002. Chemical modification of Hemp, Sisal, Jute, and Kapok fibers by alkalization. J. Appl. Polym. Sci., 84(12): 2222-2234. DOI: http://doi.org/10.1002/app.10460

Niamke FB, Amusant N, Kokutse AD, Chaix G, Charpentier JP, Adima AA, Katikoulibaly S, Jay-allemand C. 2010. Radial distribution of non-structural carbohydrates in Malaysian teak. Int. J. Biol. Chem. Sci., 4(3): 710-720. https://www.ajol.info/index.php/ijbcs/art icle/view/60498/48732

Newman RH. 1994. Crystalline forms of cellulose in softwoods and hardwoods. J. Wood Hem. Technol., 14(3): 451-466. DOI:

http://doi.org/10.1080/02773819408003 107

Newman RH. 1997. Crystalline forms of cellulose in the silver tree fern Cyathea dealbata. Cellulose, 4: 269-279. DOI: http://doi.org/10.1023/A:10184960251 43

Newman RH. 1999a. Estimation of the lateral dimension of cellulose crystallites using ${ }^{13} \mathrm{C}$ NMR signal strength. Solid State Nucl. Magn. Res., 15(1): 21-29. DOI: https://doi.org/10.1016/S09262040(99)00043-0

Newman RH, Davidson TC. 2004. Molecular conformation at the cellulose-water interface. Cellulose, 11(1): 23-32. DOI: https://doi.org/10.1023/B:CELL.0000 014778.49291.c6

Newman RH, Hemmingson JA. 1990. Determination of the degree of cellulose crystallinity in wood by carbon-13 nuclear magnetic resonance spectroscopy. Holzforschung, 44(5): 351-355.

DOI : https://doi.org/10.1515/hfsg.1990.44.5.3 51

Newman RH, Redgwell RJ. 2002. Cell wall changes in ripening kiwifruit: $13 \mathrm{C}$ solid state NMR characterization of relatively rigid cell wall polymers. Carbohydr. Polym., 49(2): 121-129. DOI : https://doi.org/10.1016/S01448617(01)00323-X
Newman RH, Hemmingson JA, Suckling ID. 1993. Carbon-13 nuclear magnetic resonance studies of kraft pulping. Holzforschung, 47(3): 234-238. DOI : https://doi.org/10.1515/hfsg.1993.47.3.2 34

Papadopoulos AN, Hill CAS, Gkaraveli A. 2003. Determination of surface area and pore volume of holocellulose and chemically modified wood flour using the nitrogen adsorption technique. Holz als-und werkstoff, 61(6): 453-456. DOI: https://doi.org/10.1007/s00107-0030430-5

Payen A. 1838. Comptes rendus hebdomadaires des séances de l'académie des sciences, 7: 1052.

Pichavant F, Mercier F. 1998. Détermination des taux d'holocellulose et d' $\alpha$-cellulose dans le bois. 1998. Procédure de laboratoire de l'Institut du Pin. Université Bordeaux 1. PR/BPC/Holo Bois/98008A.

$\mathrm{Pu}$ Y, Ziemer C, Ragauskas AJ. 2006. CP/MAS ${ }^{13} \mathrm{C}$ NMR analysis of cellulase treated bleached softwood kraft pulp. Carbohydr. Res., 341(5): 591-597. DOI: https://doi.org/10.1016/j.carres.2005.12.01 2

Richter HG, Dallwitz MJ. 2000. Commercial timbers: descriptions, illustrations, identification, and information retrieval. In English, French, German, and Spanish. Version: 4th May. http://deltaintkey.com/wood/fr/index.htm

Safou-Tchiama R, De Jéso B, Akagah AG, Sèbe G, Pétraud M. 2007. A preliminary survey of the interfacial bonding of some tropical hardwoods towards succinic anhydride and 2-octen-1-yl succinic anhydride molecules: Impact of lignin and carbohydrate polymers structure on the chemical reactivity. Ind. Crops Prod., 26(2): $\quad$ 173-184. DOI: http://doi.org/10.1016/j.indcrop.2007.03.0 01

Safou-Tchiama R, Ngwa Obame S, Brosse N, Soulounganga S, Andzi Barhé T. 2016. Investigating the potential of Aucoumea 
klaineana Pierre sapwood and heartwood wastes to produce cellulosic ethanol. Afri. J. Biotech., 15(46): 2587-2595. DOI: http://doi.org/10.5897/AJB2016.15515

Safou-Tchiama R, Andzi Barhé T, Soulounganga P, Akagah AG, De Jeso B. 2017. A comparative study of the syringyl, guaiacyl and hydroxyl groups units distribution in some African tropical hardwoods' lignin by Py-GC/MS and spectroscopic techniques. J. Mater. Env. Sci., $\quad$ 8(17): $2530-2540$. http://www.jmaterenvironsci.com/Docume nt/vol8/vol8_N7 /272-JMES-2734Tchiama.pdf

Savard J, Nicolle J, André AM. 1959. Chemical analysis of tropical woods. Tome 1. Centre technique forestier tropical. Nogent-sur-Manie, 190.

Sassi JF, Tekely P, Chanzy H. 2000. Relative susceptibility of the $\mathrm{I}_{\alpha}$ and $\mathrm{I}_{\beta}$ phase of cellulose towards acetylation. Cellulose, 7(2): 119-132. DOI: http://doi.org/10.1023/A:10092240088 02

Segal L, Creely JJ, Martin AEJ, Conrad M. 1959. An empirical method for estimating the degree of crystallinity of native cellulose using the $\mathrm{x}$-ray diffractometer. Text. Res. J., 29(10): 786-794.

DOI: http://doi.org/10.1177/00405175590290 1003

Simmons TJ, Mortimer JC, Bernardinelli1 OD, Poppler AC, Brown SP, Azevedo ER, Dupree R., Dupree Paul. 2016. Folding of xylan onto cellulose fibrils in plant cell walls revealed by solid-state NMR. Nature comm., 1-9. DOI: http://doi.org/10.1038/ncomms13902

Sun RC, Fang JM, Tomkinson J, Hill CAS. 1999. Esterification of hemicelluloses from Poplar chips in homogeneous solution of $N, N-$ dimethylformamide/lithium chloride. $J$. Wood Chem. Technol., 19(4): 287-306. DOI:

http://doi.org/10.1080/02773819909349 613

Tappi. 1988. Acid insoluble lignin in wood and pulp. In Tappi standard method $\mathrm{T}$ 222 om- 88

Tjeerdsma BF, Militz H. 2005. Chemical changes in hydrothermal treated wood: FTIR analysis of combined hydrothermal and dry heat-treated wood. Holz als Roh-und Werkstoff, 63(2): $102-111 . \quad$ DOI: http://doi.org/10.1007/s00107-0040532-8

Whitney SEC, Brighama JE, Darkea AH, Reidb GJS, Gidley MJ. 1998. Structural aspects of the interaction of mannanbased polysaccharides with bacterial cellulose. Carbohy. Res., 307(3-4): 299309. DOI: http://doi.org/10.1016/S00086215(98)00004-4

Yamamoto H, Horii F, Hirai A. 2006. Structural studies of bacterial cellulose through the solid-phase nitration and acetylation by ${ }^{13} \mathrm{C} \quad \mathrm{CP} / \mathrm{MAS}$ spectroscopy. Cellulose, 13(3): 327-342. DOI: http://doi.org/10.1007/s10570005-9034-z

Yoshimura T, Matsuo K, Fujioka R. 2006. Novel biodegradable superabsorbent hydrogels derived from cotton cellulose and succinic anhydride: Synthesis and characterization. 2006. J. Appl. Polym. Sci., 99(6): 3251-3256. DOI: http://doi.org/10.1002/app.22794

Zimnitsky DS, Yurkshtovich TL, Bychkovsky PM. 2004. Synthesis and characterization of oxidized cellulose. $J$. Appl. Polym. Sci: Part A: Polym. Chem., 42(19): 4785-4791. DOI: http://doi.org/10.1002/pola.20302 